\begin{tabular}{|c|l|}
\hline Title & $\begin{array}{l}\text { Diurnal and temporal variations of water-soluble dicarboxylic acids and related compounds in aerosols from the } \\
\text { northern vicinity of Beijing: Implication for photochemical aging during atmospheric transport }\end{array}$ \\
\hline Author(s) & He, Nannan; Kawamura, Kimitaka; Okuzawa, K.; Pochanart, P.; Liu, Y.; Kanaya, Y.; W ang, Z. F. \\
\hline Citation & $\begin{array}{l}\text { Science of The Total Environment, 499, 154.165 } \\
\text { https://doi.org/10.1016/.scitotenv.2014.08.050 }\end{array}$ \\
\hline Issue Date & 201411-15 \\
\hline Doc URL & http://hdl.handle.net/2115/57656 \\
\hline Type & article (author version) \\
\hline File Information & manuscript.pdf \\
\hline
\end{tabular}

Instructions for use 


\title{
Diurnal and temporal variations of water-soluble dicarboxylic acids and related compounds in aerosols from the northern vicinity of Beijing: Implication for photochemical aging during atmospheric transport
}

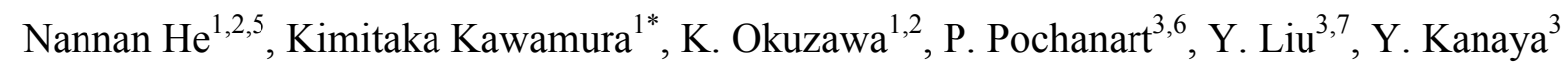 \\ and Z. F. Wang ${ }^{4}$
}

${ }^{1}$ Institute of Low Temperature Science, Hokkaido University, N19 W8, Kita-ku, Sapporo 060-0819, Japan

${ }^{2}$ Graduate School of Environmental Science, Hokkaido University, N10 W5, Kita-ku, Sapporo 060-0810, Japan

${ }^{3}$ Research Institute for Global Change, Japan Agency for Marine-Earth Science and Technology, Japan

${ }^{4}$ LAPC, Institute of Atmospheric Physics, Chinese Academy of Sciences, Beijing, China

${ }^{5}$ Now at Institute of Atmospheric Physics, Chinese Academy of Sciences, Beijing, China

${ }^{6}$ Now at National Institute of Development Administration, Bangkok 10240, Thailand

${ }^{7}$ Now at Institute for Atmospheric Physics, Chinese Academy of Sciences, Beijing 100029, China

*Corresponding author: kawamura@lowtem.hokudai.ac.jp 


\begin{abstract}
:
Aerosol samples were collected in autumn 2007 on day- and nighttime basis in the northern receptor site of Beijing, China. The samples were analyzed for total carbon (TC) and water-soluble dicarboxylic acids $\left(\mathrm{C}_{2}-\mathrm{C}_{12}\right)$, oxocarboxylic acids $\left(\mathrm{C}_{2}-\mathrm{C}_{9}\right)$, glyoxal and methylglyoxal to better understand the photochemical aging of organic aerosols in the vicinity of Beijing. Concentrations of TC are 50\% greater in daytime when winds come from Beijing than in nighttime when winds come from the northern forest areas. Most diacids showed higher concentrations in daytime, suggesting that the organics emitted from the urban Beijing and delivered to the northern vicinity in daytime are subjected to photo-oxidation to result in diacids. However, oxalic acid $\left(\mathrm{C}_{2}\right)$, which is the most abundant diacid followed by $\mathrm{C}_{3}$ or $\mathrm{C}_{4}$, became on average $30 \%$ more abundant in nighttime together with azelaic, $\omega$-oxooctanoic and $\omega$-oxononanoic acids, which are specific oxidation products of biogenic unsaturated fatty acids. Methylglyoxal, an oxidation product of isoprene and a precursor of oxalic acid, also became $29 \%$ more abundant in nighttime. Based on a positive correlation between $\mathrm{C}_{2}$ and glyoxylic acid $\left(\omega \mathrm{C}_{2}\right)$ in nighttime when relative humidity significantly enhanced, we propose a nighttime aqueous phase production of $\mathrm{C}_{2}$ via the oxidation of $\omega \mathrm{C}_{2}$. We found an increase in the contribution of diacids to TC by 3 folds during consecutive clear days. This study demonstrates that diacids and related compounds are largely produced in the northern vicinity of Beijing via photochemical processing of organic precursors emitted from urban center and forest areas.
\end{abstract}

Keywords: organic aerosols, dicarboxylic acids, oxalic acid, glyoxylic acid, photochemical aging, aqueous-phase production 


\section{Introduction}

Atmospheric particles have an influence on the global climate system, providing an adverse effect on human health and visibility (Huebert et al., 2003; Kaufman et al., 2002; Menon et al., 2002; Richter et al., 2005). Severe droughts in northern China and enhanced summer floods in southern China may be associated with the anthropogenic atmospheric particles that modify the regional air circulation (Menon et al., 2002). Dicarboxylic acids are ubiquitously present in atmospheric aerosols and they are in general the dominant class of organic components. Oxalic acid $\left(\mathrm{C}_{2}\right)$ is usually the dominant organic species in aerosols (Kawamura and Sakaguchi, 1999). Diacids are emitted primarily from combustion of fossil fuels, i.e., motor exhausts and coal burning, and biomass burning (Graham et al., 2002; Kawamura and Kaplan, 1987; Kundu et al., 2010a, b; Narukawa et al., 1999), but more importantly produced by the secondary oxidation of anthropogenic and biogenic volatile organic compounds (VOCs) in the atmosphere (Glasius et al., 2000; Kawamura et al., 2005; Kawamura et al., 1996a; Legrand et al., 2007). Aqueous-phase production of $\mathrm{C}_{2}$ is also important in aerosol/cloud/fog droplets (Warneck, 2003).

A serious air pollution is common in China due to the huge usage of fossil fuels. One fourth of primary anthropogenic organic aerosols on a global scale are produced in China, ca. $70 \%$ of which are emitted by the burning of coals (Streets et al., 2004). Beijing is located in north China with over 20 million people and 5 million motor vehicles. With several large industrial areas in Beijing, air pollution associated with ambient aerosols is the most serious social problem in the region. To suppress the aerosol concentrations in Beijing, we need to better understand chemical composition of organic aerosols and the chemical processes and photochemical aging during atmospheric transport. In the summer of 2006, a comprehensive field campaign had been performed for observation studies in the city center and also in the southern part of Beijing city (Ho et al., 2010), where dicarboxylic acids significantly contribute to water-soluble organic carbon (WSOC) but wind direction largely controls their concentrations.

However, comprehensive observations of atmospheric aerosol and gaseous components had not been performed in the northern receptor site of Beijing to which urban pollutants are 
transported in daytime by southerly winds. In the Beijing city area and its vicinity, southerly wind is dominant in daytime but at night it turns to northerly in summer and autumn. In the northern vicinity of Beijing, an extensive forest park exists and the forest areas expand to further north, we could catch the polluted air masses from Beijing in daytime and the relatively clean air masses from the northern forest areas at night. The air parcels delivered from Beijing should be highly polluted with photochemical processing during the transport. In contrast, the air parcels coming from the north where large forest expands should be less polluted.

Here, we studied aerosol samples collected in the northern vicinity of Beijing in 2007 to investigate the photochemical processing of organic aerosols with an emphasis on polar organic species and total carbon (TC). Here, we report the diurnal and temporal variations of dicarboxylic acids, $\omega$-oxocarboxylic acids, pyruvic acid and $\alpha$-dicarbonyls in early autumn. Based on the detailed molecular compositions of diacids and related compounds and their contributions to aerosol TC, we discuss photochemical aging of polar organic species during the transport in the atmosphere in day- and nighttime, and chemical processing of organic aerosols during the transport in the vicinity of megacities. We also look at ozone and its correlation with diacids.

\section{Experimentals}

\subsection{Sample collection}

We collected atmospheric aerosol samples (TSP) using a high-volume air sampler and pre-combusted quartz fiber filters at Mangshan $\left(40^{\circ} 16^{\prime} \mathrm{N}, 116^{\circ} 17^{\prime} \mathrm{E}\right), 40 \mathrm{~km}$ north of the center of Beijing, China (Figure 1). The sampling site is located next to the largest national park of natural forest in Beijing Province. No pollution source existed around the sampling site. In the north of Mangshan, there are mountain areas extended further north. In the south of the Mangshan site, urban and industrialized regions are present including Hebei, Tianjin and Beijing Provinces. The elevation of the sampling location is $187 \mathrm{~m}$ above sea level.

We collected 3-h daytime $(\mathrm{n}=26), 9$-h daytime $(\mathrm{n}=12)$, and 15-h nighttime $(\mathrm{n}=20)$ samples as well as four field-blanks during the period of 15 September to 5 October 2007. We 
placed each filter in a pre-cleaned glass jar before and after the sampling. The filter samples were frozen at $-20^{\circ} \mathrm{C}$ prior to analysis. Quartz fiber filters may adsorb organic vapors, causing positive artifacts. On the other hand, semi-volatile organics such as $\alpha$-dicarbonyls collected on the filter may partially evaporate, resulting in negative artifacts. However, such artifacts were not quantified in this study.

Meteorological parameters were obtained at the Mangshan site for wind speed/direction, ambient temperature, and relative humidity $(\mathrm{RH})$. The average daytime temperature was $25^{\circ} \mathrm{C}$ whereas the $\mathrm{RH}$ was $57 \%$. In nighttime, they were $17^{\circ} \mathrm{C}$ and $78 \%$, respectively. During daytime the wind came from the south and southwest (on average, $205^{\circ}$ ) whereas during nighttime the wind came from the northeast (on average, $30^{\circ}$ ) (Table 1). These day/night trends of local surface wind patterns are not always similar with the wind direction obtained by air mass trajectories (500 $\mathrm{m}$ above ground level). Typical transport time from downtown Beijing to Mangshan in daytime is approximately 5 hours whereas that from the nearest forest area to the sampling site in nighttime is about 1 hour or more, according to air mass trajectory analysis. Wet precipitation occurred on September 18 and 26, and October 1 and 3 to 5, although the rain of September 3-5 was very light.

We also measured ozone concentrations every one-hour at the site by UV absorption (Model 49C, Thermo Electron Corporation).

\subsection{Analytical techniques}

\subsubsection{Measurements of aerosol masses and total carbon (TC)}

The weights of filters were gravimetrically measured prior to and after the sample collection to calculate total aerosol mass concentrations. The measurement of TC was performed using an elemental analyzer (EA; model: NA 1500, Carlo Erba Instruments) with an auto sampler. A small disk $\left(3.14 \mathrm{~cm}^{2}\right)$ was cut-off from the filter and then placed in a tin cup. The tin cup samples were combusted at $1020^{\circ} \mathrm{C}$ to oxidize carbonaceous materials with chromium trioxide where the tin cup burns $\left(>1400^{\circ} \mathrm{C}\right)$ with pure $\mathrm{O}_{2}$. The $\mathrm{CO}_{2}$ produced was measured on gas chromatograph (GC) using a thermal conductivity detector. Based on triplicate 
analyses, the uncertainty in TC measurement was confirmed to be $2.5 \%$.

\subsubsection{Measurements of dicarboxylic acids, oxoacids and $\alpha$-dicarbonyls}

Details of analytical protocols are described elsewhere for the determination of diacids, oxoacids and a-dicarbonyls (Kawamura, 1993; Kawamura and Ikushima, 1993). In brief, we extracted the filter aliquots with Milli Q water to isolate organic acids and related compounds under ultrasonication. After the concentration using a rotary evaporator under vacuum, the extracts were reacted with $14 \%$ borontrifluoride $\left(\mathrm{BF}_{3}\right)$ in n-butanol at $100^{\circ} \mathrm{C}$ to derive dibutyl esters and dibutoxy acetals. The ester and acetal derivatives were measured with a capillary GC-FID (HP6890) installed with a split/splitless injector and capillary column (Kawamura and Ikushima, 1993). Authentic diacid dibutyl esters were used as external standards for the peak identification and quantification. Identifications of the organic compounds were confirmed by GC/MS analyses. We performed a recovery text of diacid standards, which showed that the recoveries are better than $70 \%$, and relative standard deviations (RSD) of diacids are $10-15 \%$. Duplicate analyses of real samples showed that the analytical uncertainties for major organic species are less than 10\%. A few organic species (e.g., oxalic, phthalic, and glyoxylic acids) were detected in the field blanks, but the blank levels are less than $10 \%$ of real samples. The concentrations reported in this study are blank-corrected.

\section{Results and discussion}

\subsection{Concentrations of TSP mass and total carbon}

During the field campaign, we found enhanced aerosol mass concentrations in daytime (see Figure 2a), with daytime mean of $270 \mu \mathrm{g} \mathrm{m}^{-3}$ (range, $48-603 \mu \mathrm{g} \mathrm{m}^{-3}$ ) and nighttime mean of $150 \mu \mathrm{g} \mathrm{m}^{-3}\left(29-270 \mu \mathrm{g} \mathrm{m}^{-3}\right)$ at Mangshan site. The greater values in daytime should be caused by the transport of polluted air parcels northward from the Beijing areas, where pollutants are seriously emitted from fossil fuel combustions. Pollutants emitted from the Beijing regions are likely delivered to the northern vicinity in daytime by southerly wind (Table 1). The daytime increase of aerosol mass may also be associated with photochemical production 
of atmospheric particles via photochemical oxidation of various gaseous precursors during the atmospheric transport from the urban regions. It is noteworthy that in nighttime wind direction shifted to northerly and hence the relatively clean air parcels were transported from the northern forest to the sampling site.

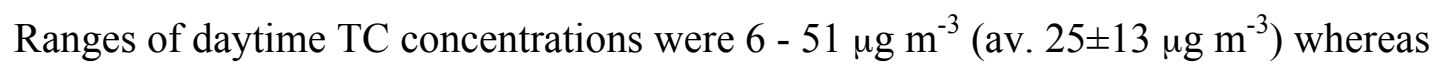
those of nighttime concentrations were $4-34 \mu \mathrm{g} \mathrm{m}^{-3}$ (av. 17 $\pm 10 \mu \mathrm{g} \mathrm{m}^{-3}$ ). They are in general greater in daytime than nighttime (Figure 2b), being consistent with aerosol mass. TC account for on average $9 \pm 2 \%$ (range: $3 \%$ to $14 \%$ ) of aerosol mass in daytime and $11 \pm 3 \%(4 \%$ to $17 \%$ ) in nighttime (Figure 2c). Generally, TC concentrations and their proportions in aerosol mass should be controlled by emission strengths, photochemical processing and/or dilution by inorganic species. TC values and their proportions to aerosol masses in Mangshan are smaller than those $\left(49 \mu \mathrm{g} \mathrm{m}^{-3}, 17 \%\right)$ reported from Beijing (Sekine et al., 1992) and those (24 $\mu \mathrm{g} \mathrm{m}^{-3}$, $21 \%$ ) from Tokyo (Kawamura and Yasui, 2005), but are significantly greater than those (0.38 $\mu \mathrm{g} \mathrm{m} \mathrm{m}^{-3}, 0.75 \%$ ) reported in the remote marine aerosols from the Pacific (Kawamura and Sakaguchi, 1999), in which sea-salts are abundant.

\subsection{Molecular distributions and temporal variations of dicarboxylic acids, oxoacids and $\alpha$-dicarbonyls}

A homologous series of $\alpha, \omega$-dicarboxylic acids $\left(\mathrm{C}_{2}-\mathrm{C}_{12}\right)$ and $\omega$-oxocarboxylic acids $\left(\omega \mathrm{C}_{2}-\omega \mathrm{C}_{9}\right)$, as well as pyruvic acid (Pyr), $\alpha$-dicarbonyls (glyoxal and methylglyoxal) and aromatic (phthalic, iso-/terephthalic) dicarboxylic acids, were detected in the samples. Table 2 summarizes their concentrations for day- and nighttime.

Concentration ranges of total dicarboxylic acids were $120-2400 \mathrm{ng} \mathrm{m}^{-3}$ (av. $1000 \pm 700$ $\left.\mathrm{ngm}^{-3}\right)$ in daytime whereas those of nighttime were $110-3100 \mathrm{ng} \mathrm{m}^{-3}\left(1200 \pm 800 \mathrm{ng} \mathrm{m}^{-3}\right)$. These concentration levels are higher than those (range 90-1370 $\mathrm{ng} \mathrm{m}^{-3}$, av. $480 \mathrm{ng} \mathrm{m}^{-3}$ ) reported in urban Tokyo, Japan (Kawamura and Ikushima, 1993). However, they are equivalent to or slightly higher than the concentrations (320-1900 $\mathrm{ng} \mathrm{m}^{-3}$, av. $900 \mathrm{ng} \mathrm{m}^{-3}$ in winter, and 210-2200 $\mathrm{ng} \mathrm{m}^{-3}$, av. $890 \mathrm{ng} \mathrm{m}^{-3}$ in summer) reported in 14 cities from China (Ho et al., 2007). They are similar with the concentrations (300-2100 $\mathrm{ng} \mathrm{m}^{-3}$ ) reported from Nanjing, China (Wang et al., 2002). 
Interestingly, abundances of diacids in Mangshan are greater than Beijing (290 - $1440 \mathrm{ng} \mathrm{m}^{-3}$, av. $760 \mathrm{ng} \mathrm{m}^{-3}$ ) (Ho et al., 2007). Higher concentrations of diacids were found in nighttime than in daytime, which is in contrast to the concentrations of TSP mass and TC. We will discuss this point later in more detail. However, the levels of diacids are significantly smaller than those (220 $-6100 \mu \mathrm{g} \mathrm{m}^{-3}$ ) from Mount Tai in North China during the agricultural burning of wheat straw wastes in May to June (Kawamura et al., 2013).

Figure 3a presents averaged molecular distributions of dicarboxylic acids and related compounds in the Mangshan aerosols for day- and nighttime. Oxalic acid $\left(\mathrm{C}_{2}\right)$ is found as the dominant diacid followed by malonic $\left(\mathrm{C}_{3}\right)$ or succinic $\left(\mathrm{C}_{4}\right)$ acid. We also found that $\mathrm{C}_{2}$ is more abundant in nighttime $\left(800 \pm 600 \mathrm{ng} \mathrm{m}^{-3}\right)$ than daytime $\left(600 \pm 400 \mathrm{ng} \mathrm{m}^{-3}\right)$. In contrast, the concentrations of $\mathrm{C}_{3}$ and $\mathrm{C}_{4}$ were lower in nighttime ( $89 \mathrm{ng} \mathrm{m}^{-3}$ and $107 \mathrm{ng} \mathrm{m}^{-3}$, respectively) than in daytime (123 $\mathrm{ng} \mathrm{m}^{-3}$ and $115 \mathrm{ng} \mathrm{m}^{-3}$, respectively). $\mathrm{C}_{2}$ can be produced by the combustion of fossil fuels (Kawamura and Kaplan, 1987) and forest fires (Narukawa et al., 1999), but more importantly produced by the photochemical oxidation of VOCs and other precursors in aerosols during long-range transport (Carlton et al., 2007; Carlton et al., 2006; Kawamura et al., 1996a; Kawamura et al., 1996b; Warneck, 2003, 2005). We also found greater levels of azelaic $\left(\mathrm{C}_{9}\right)$ acid $\left(28 \mathrm{ng} \mathrm{m}^{-3}\right)$ at night than mid-day $\left(24 \mathrm{ng} \mathrm{m}^{-3}\right) . \mathrm{C}_{9}$ is a specific oxidation product of unsaturated fatty acids (Kawamura and Gagosian, 1987; Stephanou and Stratigakis, 1993; Yokouchi and Ambe, 1986).

Phthalic acid ( $\mathrm{Ph}$ ) was found as the fourth most abundant diacid. This feature is in contrast to the Beijing aerosols where $\mathrm{Ph}$ is the $2 \mathrm{nd}$ most abundant diacid species following oxalic acid (Ho et al., 2010). $\mathrm{Ph}$ is more abundant in daytime $\left(67 \pm 6 \mathrm{ng} \mathrm{m}^{-3}\right)$ than at night $\left(42 \pm 4 \mathrm{ng} \mathrm{m}^{-3}\right)$. Concentrations of $\mathrm{Ph}$ are much higher than those (av. $29 \mathrm{ng} \mathrm{m}^{-3}$ ) from urban Tokyo in summer (Kawamura and Yasui, 2005). However, they are lower than those $\left(90 \mathrm{ng} \mathrm{m}^{-3}\right)$ from Chinese cities (Ho et al., 2007). Although Ph is directly emitted from fossil fuel combustion (Kawamura and Kaplan, 1987), secondary formation via atmospheric oxidation of aromatic hydrocarbons such as naphthalene may be more important (Ho et al., 2010; Kawamura and Ikushima, 1993). These results indicate that the aerosols from Mangshan are not so seriously polluted as the aerosols from Beijing and other urban sites in China probably due to the dilution by addition of 
other diacids from biogenic sources in the forest areas.

Concentrations of total oxocarboxylic acids ranged from 23 to $340 \mathrm{ng} \mathrm{m}^{-3}$ (av. $131 \mathrm{ng}$ $\mathrm{m}^{-3}$ ) in daytime and from 13 to $230 \mathrm{ng} \mathrm{m}^{-3}$ (av. $98 \mathrm{ng} \mathrm{m}^{-3}$ ) in nighttime. Although most oxoacids are more abundant in daytime, $\omega \mathrm{C}_{8}$ and $\omega \mathrm{C}_{9}$ acids that are produced by the oxidation of unsaturated fatty acids (Kawamura and Gagosian, 1987) are more abundant in nighttime, being consistent with azelaic $\left(\mathrm{C}_{9}\right)$ acid that showed higher concentrations in nighttime. Glyoxylic acid $\left(\omega \mathrm{C}_{2}\right)$ is the dominant oxoacid followed by Pyr and 4-oxobutanoic acid $\left(\omega \mathrm{C}_{4}\right)$. They have been considered as intermediate oxidation products of cyclic olefins (Hatakeyama et al., 1987) to produce dicarboxylic acids in the atmosphere (Kawamura and Ikushima, 1993; Kawamura et al., 1996a). Higher concentrations of oxocarboxylic acids, except for $\omega \mathrm{C}_{8}$ and $\omega \mathrm{C}_{9}$, in daytime might suggest more emissions of their precursors from anthropogenic sources. The concentrations of total oxoacids are equivalent to those from Gosan site (av. $53 \mathrm{ng} \mathrm{m}^{-3}$ ) in Jeju Island in the East China Sea (Kawamura et al., 2004) and slightly more abundant than those from urban sites in China (45 $\mathrm{ng} \mathrm{m}^{-3}$ ) (Ho et al., 2007).

Concentrations of $\alpha$-dicarbonyls ranged from $5-270 \mathrm{ng} \mathrm{m}^{-3}$ (av. $51 \pm 57 \mathrm{ng} \mathrm{m}^{-3}$ ) during mid-day and from $3.5-271 \mathrm{ng} \mathrm{m}^{-3}$ (av. 60土70 $\mathrm{ng} \mathrm{m}^{-3}$ ) at night. Glyoxal (Gly) and methylglyoxal (MeGly) are produced by gaseous-phase oxidation from various VOCs including ethylene (Ervens et al., 2004), and toluene, benzene, xylene (Volkamer et al., 2001) as well as terpenes (Fick et al., 2004) and isoprene (Zimmermann and Poppe, 1996). Interestingly, Gly showed higher concentrations in daytime whereas MeGly is more abundant in nighttime (Table 2). Gly may be associated with pollution sources whereas MeGly may be involved with biogenic sources such as isoprene. These $\alpha$-dicarbonyls may serve as the precursors to produce secondary organic aerosols through heterogeneous reactions (Kroll et al., 2005; Liggio et al., 2005). Interestingly, levels of $\alpha$-dicarbonyls in the Mangshan samples (3.5 to $271 \mathrm{ng} \mathrm{m}^{-3}$, av. $\left.54 \pm 61 \mathrm{ng} \mathrm{m}^{-3}\right)$ are several times higher than those $\left(0\right.$ to $\left.64 \mathrm{ng} \mathrm{m}^{-3}, 12 \mathrm{ng} \mathrm{m}^{-3}\right)$ from megacities in China including Beijing (Ho et al., 2007). This result emphasizes that $\alpha$-dicarbonyls are vigorously produced in the vicinity of Chinese megacity and organic aerosols are photochemically more aged than urban aerosols during the transport in the atmosphere.

Figure $3 \mathrm{~b}$ presents the variations in the abundances of total dicarboxylic acids, oxoacids 
and $\alpha$-dicarbonyls in the Mangshan aerosols. We found significant fluctuations in the concentrations of diacids and related compounds with maxima during September 16, 22, 26 and October 3 and minima during the late evening of September 17, evening of September 26, and mid-day of October 1. The minima were observed when rain events occurred. Weak wet precipitation continued from October 3 to 5 during which the levels of water-soluble organic species decreased gradually (Figure 3b). Wet precipitation (washout effect) should have scavenged diacids and related compounds from the atmosphere. $\alpha$-Dicarbonyls seem to be more significantly scavenged during the wet precipitation (Figure $3 \mathrm{~b}$ ). The atmospheric aerosols enriched with low molecular weight diacids and $\alpha$-dicarbonyls together with sulfate may act as cloud condensation nuclei during the wet precipitation (Kumar et al., 2003; Leaitch et al., 1996; $\mathrm{Yu}, 2000)$.

After the end of rainfall, concentrations of diacids and related compounds stayed low for one or two days, but they initiated to build-up. For example, their abundances showed gradual increase in the following clear days from September 19 - 22 (Figure 3b) due to the photochemical production during the transport from urban areas to the sampling site. Organic acids and $\alpha$-dicarbonyls continue to accumulate in the aerosols before the next rainfall starts to scavenge the particles on 26 September. Similar increases of diacids and related compounds were observed from 28 September to 2 October until the next rain came. The duration of this cycle (increase and decrease of the concentrations) was approximately 5-9 days in the Mangshan site during the campaign.

Principal Component Analysis (PCA) is a useful approach to verify the sources of aerosols (Hopke, 1985). It has been successfully used for a series of dicarboxylic acids and other atmospheric trace species (Fu et al., 2008; Kawamura and Sakaguchi, 1999b; Wolff and Korsog, 1985). The data sets of diacids and related compounds for daytime $(n=38)$ and nighttime $(n=20)$ aerosol samples from Mangshan were subjected to PCA analysis based on their correlation matrix, followed by the varimax rotation of the eigenvectors (Table 3 ). Three components were extracted for daytime samples and 4 components were for nighttime samples by the scree tests. Although there were no outstanding features detected among the different components, small diacids $\left(\mathrm{C}_{2}-\mathrm{C}_{6}\right)$ as well as oxoacids $\left(\mathrm{Pyr}, \omega \mathrm{C}_{2}-\omega \mathrm{C}_{9}\right)$ generally showed higher 
correlations with component 1 in both day (variance, 31\%) and night (32\%) samples. This result may demonstrate that Mangshan aerosols origin from mixed sources in both daytime and nighttime, and the organic species in aerosols are largely produced by photochemical oxidation of various anthropogenic and biogenic organic precursors (Kawamura et al., 1996a, 1996b).

\subsection{Diurnal variations of dicarboxylic acids, oxocarboxylic acids and a-dicarbonyls}

Most organic species showed higher concentrations in daytime than nighttime (Figure 3a). However, oxalic $\left(C_{2}\right)$, azelaic $\left(C_{9}\right)$, undecanedioic $\left(C_{11}\right)$, dodecanedioic $\left(C_{12}\right)$,

8-oxooctanoic $\left(\omega \mathrm{C}_{8}\right)$ and 9-oxononanoic $\left(\omega \mathrm{C}_{9}\right)$ acids showed higher concentrations in nighttime as well as maleic (M) and fumaric (F) acids and methylglyoxal (MeGly). Although all the species are largely produced by photochemical oxidation of organic precursors in daytime, additional source(s) and processes for the above-mentioned species may be present in nighttime. During daytime, wind blew from the south (Beijing) to the north (sampling site) (Table 1) and thus anthropogenic organics emitted from Beijing may be transported to the Mangshan site. The direction of wind changed at night from the south to north. Hence, the daytime aerosols originated from Beijing and delivered to the north likely came back at night to the site of Mangshan by north winds with an addition of biogenic emissions from the forest areas, north of Beijing. Interestingly, specific oxidation products of biogenic unsaturated fatty acids (i.e., $\mathrm{C}_{9}$, $\omega \mathrm{C}_{8}$, and $\omega \mathrm{C}_{9}$ ) (Kawamura and Gagosian, 1987) became more abundant in nighttime (Table 2, Figure 3a). The relative abundances of $\mathrm{Ph}$ in total diacids clearly increased in daytime (Figure $\mathrm{S} 2 \mathrm{a})$. This result indicates that anthropogenic contributions are more serious during daytime.

Malonic acid $\left(\mathrm{C}_{3}\right)$ can be formed by the photochemical breakdown of succinic acid $\left(\mathrm{C}_{4}\right)$ and thus $\mathrm{C}_{3} / \mathrm{C}_{4}$ ratio has been used as an indicator of enhanced photochemical aging of organic aerosols (Aggarwal and Kawamura, 2008; Kawamura and Ikushima, 1993). Lower $\mathrm{C}_{3} / \mathrm{C}_{4}$ ratios $(0.2-0.4$, av. 0.3$)$ have been reported in vehicular exhaust in comparison to those $(0.6-2.9$, av. 1.6) of atmospheric particles (Kawamura and Kaplan, 1987) because $C_{3}$ is thermally more unstable compared to $\mathrm{C}_{4}$ during high-temperature combustion (Kawamura and Ikushima, 1993). In this study, $\mathrm{C}_{3} / \mathrm{C}_{4}$ ratios became higher in daytime (0.7 to 3.8 , av. $\left.1.2 \pm 0.6\right)$ than in nighttime (0.5 to 1.8 , av. $1.0 \pm 0.4)$. These ratios from Mangshan are much greater than that (0.6) from 
summer aerosols in northern Chinese cities (Ho et al., 2007). These comparisons suggest that a secondary formation of diacids and the subsequent aging occur more frequently in the vicinity of Beijing than urban site. Very high $\mathrm{C}_{3} / \mathrm{C}_{4}$ ratios (2.6-3.7) were obtained on 17 to 18 September after the end of rainfall (Figure $S 2 b$ ). This result suggests that $C_{3}$ is vigorously produced under a strong solar radiation by photochemical oxidation of $\mathrm{C}_{4}$ (Kawamura et al., 1996a).

$\mathrm{C}_{6}$ diacid is formed by the ozone oxidation of cyclohexene (Grosjean et al., 1978; Hatakeyama et al., 1987). On the other hand, $\mathrm{C}_{9}$ is produced by the oxidation of biogenic unsaturated fatty acids (Kawamura and Gagosian, 1987; Stephanou and Stratigakis, 1993). Thus $\mathrm{C}_{6} / \mathrm{C}_{9}$ ratio has been utilized as a tracer to estimate the anthropogenic v.s. biogenic contributions to organic aerosols (Kawamura and Yasui, 2005). In the present study, $\mathrm{C}_{6} / \mathrm{C}_{9}$ ratios present greater values during daytime $(0.5-2.0$, av. $0.9 \pm 0.4)$ than nighttime $(0.2-1.2$, av. $0.6 \pm 0.2$ ) (see Figure S2c). These results suggest that anthropogenic source is more important in daytime than in nighttime whereas biogenic organic compounds more contribute in nighttime to the Mangshan organic aerosols.

$\mathrm{C}_{11}-\mathrm{C}_{12}$ dicarboxylic acids are produced by the oxidation of unsaturated fatty acids (Kawamura and Gagosian, 1987) although $\omega$-oxidation of monocarboxylic acids could produce corresponding $\alpha, \omega$-dicarboxylic acids. Interestingly, their abundances are higher in nighttime than daytime within the same date; average nighttime/daytime concentration ratios of $\mathrm{C}_{9}, \mathrm{C}_{11}$ and $\mathrm{C}_{12}$ were 1.2, 1.7 and 2.3, respectively. The present results again demonstrate an importance of biogenic unsaturated fatty acids as sources of water-soluble organic aerosols via the oxidation at nighttime. Because vaccenic acid $\left(\mathrm{C}_{18: 1} \omega_{7}\right)$, a positional isomer of oleic acid, is derived from bacterial cell membrane (Kawamura and Gagosian, 1987), the predominance of undecanedioic acid $\left(\mathrm{C}_{11}\right)$ in the range of $\mathrm{C}_{10}-\mathrm{C}_{12}$ diacids in nighttime (Table 2) suggests that bacterial lipids are more contributed to the aerosols and oxidized at night. Bacterial growth may be possible in wetted aerosols at night under the high RH.

Relative abundances of oxalic acid in total diacids ranged from $<40 \%$ to $>75 \%$. An increased $\mathrm{C}_{2} /$ total diacid ratio has been reported in the marine aerosols from the Pacific during the long-range atmospheric transport (Kawamura and Sakaguchi, 1999a) and used as a proxy of 
photochemical aging of organic aerosols (Kawamura and Yasui, 2005). Interestingly, the ratios of $\mathrm{C}_{2}$ /total diacids are generally higher in nighttime than daytime (Figure $\mathrm{S} 2 \mathrm{~d}$ ), probably due to the preferential production of oxalic acid in nighttime via the oxidation of its precursors in the aerosol particles. Further, the ratios in daytime showed an increase from 18 to 24 September and 27 September to 1 October when clear sky condition continued after the end of rain. Photochemical aging of organic aerosols probably result in the increase of $\mathrm{C}_{2} /$ total diacid ratios. During these periods, oxalic acid should have accumulated in aerosols due to the photochemical production via the oxidation of various precursors.

\subsection{Enhanced contributions of diacids, oxoacids and $\alpha$-dicarbonyls to aerosol TC}

Figure 4 presents temporal variations in the contributions of total diacids and oxalic acid to aerosol total carbon (TC). Total diacid-C/TC ratios ranged from $0.4 \%$ to $3.6 \%$ (av. $1.8 \pm 0.7 \%$ ) in daytime and from $0.9 \%$ to $9.7 \%$ (av. $3.0 \pm 2.1 \%$ ) in nighttime. Interestingly, total diacid-C/TC ratios are generally higher in nighttime than in daytime (see black circles for nighttime in Figure 4). Oxalic acid-C/TC (\%) ranged from $0.1 \%$ to $1.2 \%$ (av. $0.7 \pm 0.3 \%$ ) in daytime and from $0.3 \%$ to $4.3 \%$ (av. $1.2 \pm 0.9 \%$ ) in nighttime. The average ratio in nighttime is almost twice higher than that of nighttime, suggesting that oxalic acid is more produced in nighttime. This point will be discussed in more detail in section 3.6. Although TC includes elemental carbon (EC), averaged EC/TC ratio was 0.16 (Taketani et al., 2008, unpublished result), suggesting that the above ratios may not be seriously affected by the variation of EC.

Contributions of total diacids and oxalic acid to aerosol TC increased after the rainfall ended on 17 September, from which a clear sky condition continued until 24 September

(Figures $3 \mathrm{~b}$ and 5). Total diacid-C/TC and oxalic acid-C/TC ratios also increased gradually by 3 fold from 26 September to 1 October before another rain came. These results suggest that polar diacids are more enriched in organic aerosols during the back and forth movement of air parcels between Beijing and northern forest areas due to photochemical aging of organic aerosols. However, aging of organic aerosols was reset by wet precipitation, although photochemical aging again initiated under the fine conditions after the end of rain. Enhanced contributions of diacids to TC were detected at nighttime (18h-9h) during 3-5 October (Figure 4) when light rain 
or cloud condition continued (Figure 3b). Being different from other sampling periods, the 6-day backward air mass trajectories in nighttime did not reach the remote regions but hovered over Beijing and its vicinities with the southerly winds that bring the urban pollutants to the sampling site (see Figure S1 for air mass trajectories). These meteorological situations may cause the higher oxalic acid-C/TC ratios. Alternatively, coarse particles that contained high abundance of TC might be preferentially scavenged from the atmosphere during light rain, causing higher oxalic acid-C/TC ratios in the fine particles.

The contributions of total diacids to TC in Mangshan aerosols (0.4-9.6\%, av. $2.2 \pm 1.4 \%$ ) are equivalent to those (1.2-6.6\%, av. 2.4\%) reported for the Mt. Tai aerosols in North China during biomass burning of agriculture residue (wheat straw) in late May to early June (Kawamura et al., 2013). These values are significantly higher than those $(0.2-1.8 \%$, av. $1.0 \%$ ) reported in the urban Tokyo aerosols (Kawamura and Ikushima, 1993) and those $(0.3-2.1 \%$, av. $0.9 \%)$ reported in the marine aerosols from the Arctic Ocean in summer (Kawamura et al., 2012). However, they are lower than those (1.5-7.0\%, av. 4.0\%) reported in the Arctic (Alert) aerosols from February to June including a polar sunrise season (Kawamura et al., 2010) and are significantly lower than those (1.1-15.8\%, av. 8.8\%) reported in the remote marine aerosols collected from the North to Central Pacific including tropics (Kawamura and Sakaguchi, 1999a). We found that photochemical aging of organic aerosols and the reset by wet precipitation significantly control the contributions of diacids to TC.

\subsection{Relations of diacids with ozone}

During the campaign, $\mathrm{O}_{3}$ concentrations ranged from 12 to $148 \mathrm{ppbv}$ in daytime and from 10 to $70 \mathrm{ppbv}$ in nighttime. Although very high levels of ozone were found in daytime, the levels stayed sometimes high even at night. Temporal variations of ozone for daytime and nighttime, respectively, together with total diacid concentrations are represented in supplementary Figure S3. Interestingly, a fairly good correlation was obtained between ozone and total diacid concentrations for both day- and nighttime with the correlation coefficient $\left(\mathrm{r}^{2}\right)$ of 0.23 and 0.25 , respectively. These results suggest that diacids are secondarily produced in the atmosphere via the oxidation of various organic precursors. It is also important to note that the 
highest ozone concentration was recorded at $12 \mathrm{~h}-15 \mathrm{~h}$ of 22 September when dicarboxylic acids peaked, suggesting that ozone and other oxidants may be involved with the production of diacids.

Oxalic acid showed a good correlation with ozone in daytime $\left(\mathrm{r}^{2}=0.30\right)$, but no correlation (0.06) was found in nighttime. Interestingly, malonic acid strongly correlated with ozone (0.59) in daytime, but no correlation (0.03) was found in nighttime. Succinic acid showed a weak correlation in daytime (0.19), but there is no correlation (0.01) in nighttime. Other organic species did not show any correlations with ozone, except for phthalic acid (0.21) and glyoxylic acid (0.41) in daytime. These results support that oxalic, malonic, and succinic acids as well as phthalic and glyoxylic acids are produced by the photochemical oxidation of organic precursors, or these acids are produced together with ozone in daytime. The low correlation coefficients of ozone and oxalic and other diacids in nighttime may suggest that the nighttime chemistry of diacids is mainly initiated with $\mathrm{NO}_{3}$ radical and other oxidizing agents such as $\mathrm{H}_{2} \mathrm{O}_{2}$ (Claeys et al., 2004; Herrmann et al., 2000).

\subsection{Possible production of oxalic acid in nighttime}

Concentrations of $\mathrm{C}_{2}$ are greater at night than mid-day with its average night-to-day concentration ratio of 1.3. The aerosol study from New Delhi reported the similar result; the average night-to-day ratio is ca. 2 (Miyazaki et al., 2009). Although lower levels of the nighttime boundary layer may enhance the diacid concentrations, we detected a preferential increase of $\mathrm{C}_{2}$ in nighttime whereas other diacids such as $\mathrm{C}_{3}$ and $\mathrm{C}_{4}$ did not show any increase as stated before. Because $\mathrm{C}_{2}$ could be formed by the oxidation of higher molecular weight diacids (Kawamura et al., 1996b), ratios of $\mathrm{C}_{2}$ /total diacids can be used as a proxy of photochemical aging of organic aerosols (Kawamura and Sakaguchi, 1999a). The ratios should become higher with the progress of photochemical aging of organic aerosols. The higher ratios of $\mathrm{C}_{2}$ /total diacids in nighttime indicate that organic aerosols are more enriched with oxalic acid by chemical processing at night.

Some laboratory studies demonstrated that aqueous phase reactions to produce $\mathrm{C}_{2}$ could be mainly initiated in nighttime by $\mathrm{NO}_{3}$ (Herrmann et al., 2000) and $\mathrm{H}_{2} \mathrm{O}_{2}$ (in the presence of 
$\mathrm{H}_{2} \mathrm{SO}_{4}$ ) (Claeys et al., 2004), although $\mathrm{NO}_{3}$ reactions are usually slow. Because the nighttime $\mathrm{RH}$ increased significantly (up to $100 \%$, on average $78 \%$ ), $\mathrm{C}_{2}$ could be produced in aqueous phase in nighttime. Biogenic and anthropogenic VOCs can react with oxidants to produce methylglyoxal (MeGly) and glyoxal (Gly) in gas phase. During mid-day, OH radicals are important oxidants (Fan and Zhang, 2004) as well as $\mathrm{O}_{3}$ (Kamens et al., 1982). In contrast, the nighttime oxidant is mainly $\mathrm{NO}_{3}$, which attacks biogenic (such as monoterpenes and isoprene) and anthropogenic VOCs (Warneke et al., 2004). Thus, VOCs and their oxidation products may serve as precursors in nighttime. MeGly and Gly are produced in gas phase and can be hydrated in aqueous phase to result in $\mathrm{CH}_{3} \mathrm{COCH}(\mathrm{OH})_{2}$ and $(\mathrm{OH})_{2} \mathrm{CHCH}(\mathrm{OH})_{2}$, respectively. The hydrated MeGly is further reacted with oxidants, resulting in Pyr, acetic acid, hydrated $\omega \mathrm{C}_{2}$, and finally $\mathrm{C}_{2}$. Similarly, hydrated Gly can be converted to $\omega \mathrm{C}_{2}$, and then $\mathrm{C}_{2}$ (Lim et al., 2005; Sorooshian et al., 2007).

Once oxalic acid is formed, it can stay longer in aerosols because all the carbons in oxalic acid are already oxidized and there is no hydrogen atom to be subtracted by $\mathrm{OH}$ radicals. At Mangshan site, $\mathrm{C}_{2}$ should be more produced than other diacids because $\mathrm{C}_{2}$ precursors (e.g., Gly, $\omega C_{2}$ ) are more abundant than $\geqq C_{3}$ precursors such as $\omega C_{3}$ and $\omega C_{4}$ (Table 2). In fact, when $\mathrm{C}_{2}$ became more abundant in nighttime, $\omega \mathrm{C}_{2}$ became less abundant in nighttime (Figure $3 a)$. We found a good positive correlation between $C_{2}$ and $\omega C_{2}$ in both daytime $\left(R^{2}=0.76\right)$ and nighttime $\left(\mathrm{R}^{2}=0.68\right)$, although the slope of the regression line is greater in nighttime. Hence, the ratios of $\mathrm{C}_{2} /$ total diacids could be enhanced in nighttime. These results suggest that $\mathrm{C}_{2}$ is partly produced via the oxidation of $\omega_{2}$, which may be derived from MeGly and Gly (Ervens and Volkamer, 2010). Oxidation of biogenic VOCs (e.g., isoprene) emitted from the forest areas in the north during daytime produces $\alpha$-dicarbonyls, which may be transported to the Mangshan site in nighttime, and finally oxidized to $\omega \mathrm{C}_{2}$ and then $\mathrm{C}_{2}$ in aqueous phase as discussed above.

We also found that $\mathrm{C}_{2}$ and $\mathrm{C}_{3}$ positively correlate in day $\left(\mathrm{R}^{2}=0.81\right)$ and night $\left(\mathrm{R}^{2}=0.68\right)$, although the slope of regression line is twice greater in nighttime than daytime. These results suggest that the production of $\mathrm{C}_{2}$ from $\mathrm{C}_{3}$ is more significant in nighttime than in mid-day. Although we obtained similar difference in the regression line for $\mathrm{C}_{2}$ and $\mathrm{C}_{4}$, the difference is 
smaller between mid-day $\left(\mathrm{R}^{2}=0.88\right)$ and night $\left(\mathrm{R}^{2}=0.60\right)$. We consider that secondary formation of $\mathrm{C}_{2}$ is probably caused by the liquid-phase oxidation of $\mathrm{C}_{2}$ precursors (e.g., $\omega \mathrm{C}_{2}$ ) that are derived from biogenic sources at night. In daytime, $\mathrm{C}_{2}$ is primarily produced by fossil fuel combustion (i.e., coal burning and motor exhaust) in urban regions, and formed secondarily by the photochemical processing of anthropogenic organic compounds during the transport.

Although there is a clear split between day and nighttime samples for higher concentrations of diacids ( $>500 \mathrm{ng} \mathrm{m}^{-3}$ ), most points at lower concentrations seem to exist on the same line (Figure 5a-c), which are mostly associated with wet precipitation and then scavenging from the atmosphere (Figure 3b).

Further, $\mathrm{C}_{9}$ diacid and $\omega \mathrm{C}_{8}$ and $\omega \mathrm{C}_{9}$ oxoacids, which are specific oxidation products of biogenic unsaturated fatty acids as stated earlier (Kawamura and Gagosian, 1987; Yokouchi and Ambe, 1986), presented greater abundances at night than mid-day. The present result indicates that unsaturated fatty acids are important precursors to result in the production of these $\mathrm{C}_{8}$ and $\mathrm{C}_{9}$ species via liquid-phase reactions at night. Photochemical breakdown of $\mathrm{C}_{9}, \omega \mathrm{C}_{8}$ and $\omega \mathrm{C}_{9}$ may produce small dicarboxylic acids including $\mathrm{C}_{4}, \mathrm{C}_{3}$, and $\mathrm{C}_{2}$, as illustrated in Figure 6. Although oxalic acid is known to produce via fossil-fuel combustion, its relatively high abundance in the remote atmosphere, coupled with the estimated lifetime of 6-8 days, may demonstrate either a background presence or secondary production from anthropogenic and natural precursors (Graham et al., 2002; Myriokefalitakis et al., 2011).

\subsection{Potential photolysis of oxalic acid in daytime}

Previous studies reported that Fe(III)-oxalato complexes exist in the atmosphere, which can photo-decompose in aqueous phase serving as a sink of oxalic, glyoxylic and pyruvic acids in the atmosphere (Ervens et al., 2003; Pavuluri and Kawamura, 2012; Zuo and Hoigne, 1992, 1994). Those organic acids can act as ligands to coordinate with iron, forming organic acid-iron complexes. Thus, they have a significant effect on the speciation and reactivity of Fe(III) in atmospheric water (Zuo and Zhan, 2005). Fe(III) in the atmosphere is commonly emitted from both natural and anthropogenic sources (Zhu et al., 1993). Iron should be abundantly present in continental aerosols although we did not measure Fe(III) in this study. This loss mechanism is 
strongly dependent on solar radiation, $\mathrm{pH}$, and abundances of iron (Zuo and Hoigne, 1992). Oxalate is more effectively destructed by photolysis of the complexes than the destruction by hydroxyl radicals (Zuo and Hoigne, 1992, 1994).

Typical transport time from urban Beijing to Mangshan is approximately 5 hours for daytime samples as stated above, whereas that from the forest area is 1 hour (or more) for nighttime samples because the sampling site is adjacent to the main forest area. The time scale for photolysis of $\mathrm{Fe}$-oxalato complex in aqueous phase is approximately 60 minutes (Zuo and Zhan, 2005), which means that such reaction can be sufficiently carried out during the atmospheric transport. Hence, oxalic acid is likely destroyed in daytime via the photo-decomposition of Fe-oxalato complexes in aerosols. We consider that $\mathrm{C}_{2}$ can be generated by the oxidation of precursors in aerosol waters in nighttime during the transport of the polluted air parcels from the north to Mangshan. However, it can be in part decomposed during mid-day by iron(III)-catalyzed photolysis in wetted aerosols. Malonic acid could also decompose in the presence of Fe (III), but the decomposition rate of its Fe-complex is ca. 20 times lower than that of oxalic acid (Faust and Zepp, 1993).

\subsection{Comparison of Mangshan diacid concentrations with other geographical sites}

We compare the atmospheric abundances of total dicarboxylic acids as well as oxalic acid in aerosols from the Mangshan site with those from various sites in East Asia and other parts of the world (Figure 7). In East Asia, atmospheric aerosols are often influenced by long-range transport of pollutants from various regions during monsoon season. The abundances of total dicarboxylic acids and $\mathrm{C}_{2}$ are much greater in the samples from Mangshan than those from Gosan, Tokyo and Chinese cities. These comparisons demonstrate that that the aerosols from Mangshan are significantly enriched with diacids possibly due to the photochemical production during atmospheric transport. But, their concentrations are smaller than those from the summit of Mt. Tai, which are heavilly affected by agriculture-waste burning as described above. Since the sampling site of Mangshan locates at the northern vicinity of Beijing (see Figure 1), it is significantly affected by the atmospheric transport of pollutants from Beijing as well as biogenic VOCs emitted from forest areas. 
We found that concentrations of diacids in Mangshan are ca. 20-30\% higher than those from the Beijing urban center (Ho et al., 2010). Our finding demonstrates that organic precursors are photochemically processed in the vicinity of megacities during the atmospheric transport, producing water-soluble organic acids that are important components of organic aerosols in China. Photochemical processing of organic aerosols and their precursors during the transport may be more important for the production of atmospheric particles in the vicinities of megacities rather than urban centers in China. Finally, concentrations of diacids in Asian aerosols are much higher than those from remote marine, arctic and Antarctic regions as expected (Figure 7).

\section{Conclusions}

Molecular distributions of dicarboxylic acids in the aerosol samples from the northern vicinity of Beijing, China were characterized by the predominance of oxalic $\left(\mathrm{C}_{2}\right)$ acid followed by succinic $\left(\mathrm{C}_{4}\right)$ or malonic $\left(\mathrm{C}_{3}\right)$ acid. Phthalic acid $(\mathrm{Ph})$ was found as the fourth most abundant diacid with higher concentrations in daytime than nighttime, being in contrast to urban Beijing where $\mathrm{Ph}$ was the second dominant diacid following $\mathrm{C}_{2}$. $\mathrm{Ph}$ is probably more produced in daytime due to the atmospheric oxidation of aromatic hydrocarbons such as naphthalenes, which should be emitted from anthropogenic sources in Beijing and transported in daytime to northern vicinities by south wind.

We found greater abundances of $\mathrm{C}_{2}$ and zelaic $\left(\mathrm{C}_{9}\right)$ acid at night as well as $\omega \mathrm{C}_{8}$ and $\omega \mathrm{C}_{9}$ oxoacids that are specifically produced by the oxidation of unsaturated fatty acids. We propose that an aqueous phase production of $\mathrm{C}_{2}$ and $\mathrm{C}_{9}$ may be important in nighttime ( $\mathrm{RH}$ often reached to $100 \%$ ) during the transport of the mixed (both biogenic and anthropogenic) air masses from the forest area to the Mangshan site by the southward winds. It is also possible that $\mathrm{C}_{2}$ could partly be photolyzed in daytime via the decomposition of iron(III)-oxalate complex in atmospheric waters.

We also discovered that contributions of diacids to TC are $70 \%$ higher in nighttime than daytime and that they gradually increased by three times in the northern vicinity of Beijing for 
consecutive 3-5 clear days after the rainfall due to the photochemical aging of organic aerosols during the atmospheric transport. Further, diacids and related compounds in Mangshan (vicinity) were found to be more abundant than in megacity Beijing, indicating that photochemical production and processing (aging) of water-soluble organic acids and related compounds are more significant in the northern vicinity of Beijing rather than the urban center.

Finally, the present observation study provides an atmospheric contemporary reference for the current studies of the heavily polluted air conditions in Beijing where an extremely high loading of $\mathrm{PM}_{2.5}$ causes a serious haze in winter. The outcome of this research opened a special angle to examine the causes of the high loading of $\mathrm{PM}_{2.5}$ in Beijing. It may be associated with high abundances of water-soluble organic aerosols that are photochemically produced and accumulated in the atmosphere of Beijing and its vicinity during the day/night transport (back and forth of air masses).

\section{Acknowledgements}

We acknowledge the financial support by Japan Society for the Promotion of Science (JSPS) through grant-in-aid Nos. 19204055 and 24221001. The financial support by the Global Environment Research Fund (B-051) of the Ministry of the Environment, Japan should also be acknowledged for the sending of the analytical equipment to the Mangshan site. The authors thank Yuzo Miyazaki and Pingqing Fu for their helpful comments. The authors gratefully appreciate the NOAA Air Resources Laboratory (ARL) for the provision of the HYSPLIT transport and dispersion model (http://www.ready.noaa.gov). Our data is not publicly available. 


\section{References}

Aggarwal, S.G., Kawamura, K., 2008. Molecular distributions and stable carbon isotopic compositions of dicarboxylic acids and related compounds in aerosols from Sapporo, Japan: Implications for photochemical aging during long-range atmospheric transport. J. Geophys. Res.-Atmos. 113, doi:10.1029/2007jd009365.

Carlton, A.G., Turpin, B.J., Altieri, K.E., Seitzinger, S., Reff, A., Lim, H.J., Ervens, B., 2007. Atmospheric oxalic acid and SOA production from glyoxal: Results of aqueous photooxidation experiments. Atmos. Environ. 41, 7588-7602.

Carlton, A.G., Turpin, B.J., Lim, H.J., Altieri, K.E., Seitzinger, S., 2006. Link between isoprene and secondary organic aerosol (SOA): Pyruvic acid oxidation yields low volatility organic acids in clouds. Geophys. Res. Lett. 33, L06822.

Claeys, M., Graham, B., Vas, G., Wang, W., Vermeylen, R., Pashynska, V., Cafmeyer, J., Guyon, P., Andreae, M.O., Artaxo, P., Maenhaut, W., 2004. Formation of secondary organic aerosols through photooxidation of isoprene. Science 303, 1173-1176.

Ervens, B., Feingold, G., Frost, G.J., Kreidenweis, S.M., 2004. A modeling study of aqueous production of dicarboxylic acids: 1. Chemical pathways and speciated organic mass production. J. Geophys. Res.-Atmos. 109, D15205, doi: 10.1029/2003jd004387.

Ervens, B., George, C., Williams, J.E., Buxton, G.V., Salmon, G.A., Bydder, M., Wilkinson, F., Dentener, F., Mirabel, P., Wolke, R., Herrmann, H., 2003. CAPRAM 2.4 (MODAC mechanism): An extended and condensed tropospheric aqueous phase mechanism and its application. J. Geophys. Res.-Atmos. 108.

Ervens, B., Volkamer, R., 2010. Glyoxal processing by aerosol multiphase chemistry: towards a kinetic modeling framework of secondary organic aerosol formation in aqueous particles. Atmos. Chem. Phys. 10, 8219-8244.

Fan, J.W., Zhang, R.Y., 2004. Atmospheric Oxidation Mechanism of Isoprene. Environ. Chem. 1, 140-149.

Faust, B.C., Zepp, R.G., 1993. Photochemistry of Aqueous Iron(III) Polycarboxylate Complexes - Roles in the Chemistry of Atmospheric and Surface Waters. Environ. Sci. Technol. 27, 2517-2522.

Fick, J., Nilsson, C., Andersson, B., 2004. Formation of oxidation products in a ventilation system. Atmos. Environ. 38, 5895-5899.

Fu, P.Q., Kawamura, K., Okuzawa, K., Aggarwal, S.G., Wang, G., Kanaya, Y., Wang, Z., 2008. Organic molecular composi- tions and temporal variations of summertime mountain aerosols over Mt. Tai, North China Plain. J. Geophys. Res.-Atmos. 113.

Glasius, M., Lahaniati, M., Calogirou, A., Di Bella, D., Jensen, N.R., Hjorth, J., Kotzias, D., Larsen, B.R., 2000. Carboxylic acids in secondary aerosols from oxidation of cyclic monoterpenes by ozone. Environ. Sci. Technol. 34, 1001-1010.

Graham, B., Mayol-Bracero, O.L., Guyon, P., Robert, G.C., Decesari, S., Facchini, M.C., Artaxo, P., Maenhaut, W., P., K., Andreae, M.O., 2002. Water-soluble organic compounds in biomass burning aerosols over Amazonia: 1. Characterization by NMR and GC-MS. J. Geophys. Res. 107, D20, 8047, doi:8010.1029/2001JD000336.

Grosjean, D., Vancauwenberghe, K., Schmid, J.P., Kelley, P.E., Pitts, J.N., 1978. Identification of C3-C10 Aliphatic Dicarboxylic-Acids in Airborne Particulate Matter. Environ Sci Technol 12, 313-317.

Hatakeyama, S., Ohno, M., Weng, J.H., Takagi, H., Akimoto, H., 1987. Mechanism for the Formation of Gaseous and Particulate Products from Ozone-Cycloalkene Reactions in Air. Environ. Sci. Technol. 21, 52-57.

Herrmann, H., Ervens, B., Jacobi, H.W., Wolke, R., Nowacki, P., Zellner, R., 2000. CAPRAM2.3: A chemical aqueous phase radical mechanism for tropospheric chemistry. J. Atmos. Chem. 36, 231-284.

Ho, K.F., Cao, J.J., Lee, S.C., Kawamura, K., Zhang, R.J., Chow, J.C., Watson, J.G., 2007. Dicarboxylic acids, ketocarboxylic acids, and dicarbonyls in the urban atmosphere of China. J. Geophys. Res.-Atmos .112.

Ho, K.F., Lee, S.C., Ho, S.S.H., Kawamura, K., Tachibana, E., Cheng, Y., Zhu, T., 2010. Dicarboxylic acids, ketocarboxylic acids, alpha-dicarbonyls, fatty acids, and benzoic acid in urban aerosols collected during the 2006 Campaign of Air Quality Research in Beijing (CAREBeijing-2006). J. 
Geophys. Res.-Atmos. 115, doi:10.1029/2009jd013304.

Hopke, P.K., 1985. Receptor Modeling in Environmental Chemistry. John Wiley \& Sons, New York.

Huebert, B.J., Bates, T., Russell, P.B., Shi, G.Y., Kim, Y.J., Kawamura, K., Carmichael, G., Nakajima, T., 2003. An overview of ACE-Asia: Strategies for quantifying the relationships between Asian aerosols and their climatic impacts. J. Geophys. Res.-Atmos 108, doi:10.1029/2003JD003550.

Kamens, R.M., Gery, M.W., Jeffries, H.E., Jackson, M., Cole, E.I., 1982. Ozone-Isoprene Reactions Product Formation and Aerosol Potential. Int. J. Chem. Kinet 14, 955-975.

Kaufman, Y.J., Tanre, D., Boucher, O., 2002. A satellite view of aerosols in the climate system. Nature 419, 215-223.

Kawamura, K., 1993. Identification of C2-C10 $\omega$-oxocarboxylic acids, pyruvic acid, and C2-C3 $\alpha$-dicarbonyls in wet precipitation and aerosol samples by capillary GC and GC/MS. Analytical Chemistry 65, 3505-3511.

Kawamura, K., Gagosian, R.B., 1987. Implications of $\omega$-oxocarboxylic acids in the remote marine atmosphere for photo-oxidation of unsaturated fatty acids. Nature 325, 330-332.

Kawamura, K., Ikushima, K., 1993. Seasonal changes in the distribution of dicarboxylic acids in the urban atmosphere. Environ. Sci. Technol. 27, 2227-2235.

Kawamura, K., Imai, Y., Barrie, L.A., 2005. Photochemical production and loss of organic acids in high Arctic aerosols during long-range transport and polar sunrise ozone depletion events. Atmos. Environ. 39, 599-614.

Kawamura, K., Kaplan, I.R., 1987. Motor Exhaust Emissions as a Primary Source for Dicarboxylic-Acids in Los-Angeles Ambient Air. Environ. Sci. Technol. 21, 105-110.

Kawamura, K., Kasukabe, H., Barrie, L.A., 1996a. Source and reaction pathways of dicarboxylic acids, ketoacids and dicarbonyls in arctic aerosols: One year of observations. Atmos. Environ. 30, 1709-1722.

Kawamura, K., Kasukabe, H., Barrie, L.A., 2010. Secondary formation of water-soluble organic acids and $\alpha$-dicarbonyls and their contributions to total carbon and water-soluble organic carbon: Photochemical aging of organic aerosols in the Arctic spring. J. Geophys. Res.-Atmos. 115, D21306, doi:10.1029/2010jd014299.

Kawamura, K., Kobayashi, M., Tsubonuma, N., Mochida, M., Watanabe, T., Lee, M., 2004. Organic and inorganic compositions of marine aerosols from East Asia: Seasonal variations of water-soluble dicarboxylic acids, major ions, total carbon and nitrogen, and stable $\mathrm{C}$ and $\mathrm{N}$ isotopic composition, in: Hill, R.J., Leventhal, J., Aizenshtat, Z., Baedecker, M.J., Claypool, G., Eganhouse, R., Goldhaber, M., Peters, K. (Eds.), Geochemical Investigations in Earth and Space Science: A Tribute to Isaac R. Kaplan. The Geochemical Society, pp. 243-265.

Kawamura, K., Ono, K., Tachibana, E., Charriére, B., Sempéré, R., 2012. Distributions of low molecular weight dicarboxylic acids, ketoacids and $\alpha$-dicarbonyls in the marine aerosols collected over the Arctic Ocean during late summer. Biogeosciences 9, 4725-4737.

Kawamura, K., Sakaguchi, F., 1999a. Molecular distributions of water soluble dicarboxylic acids in marine aerosols over the Pacific Ocean including tropics. J. Geophys. Res.-Atmos. 104, D3, 3501-3509.

Kawamura, K., Sempéré, R., Imai, Y., Fujii, Y., Hayashi, M., 1996b. Water soluble dicarboxylic acids and related compounds in Antarctic aerosols. J. Geophys. Res.-Atmos. 101, 18721-18728.

Kawamura, K., Tachibana, E., Okuzawa, K., Aggarwal, S.G., Kanaya, Y., Wang, Z.F., 2013. High abundances of water-soluble dicarboxylic acids, ketocarboxylic acids and alpha-dicarbonyls in the mountaintop aerosols over the North China Plain during wheat burning season. Atmos. Chem. Phys. $13,8285-8302$.

Kawamura, K., Yasui, O., 2005. Diurnal changes in the distribution of dicarboxylic acids, ketocarboxylic acids and dicarbonyls in the urban Tokyo atmosphere. Atmos. Environ. 39, 1945-1960.

Kroll, J.H., Ng, N.L., Murphy, S.M., Flagan, R.C., Seinfeld, J.H., 2005. Secondary organic aerosol formation from isoprene photooxidation under high-NOx conditions. Geophys. Res. Lett. 32.

Kumar, P.P., Broekhuizen, K., Abbatt, J.P.D., 2003. Organic acids as cloud condensation nuclei: Laboratory studies of highly soluble and insoluble species. Atmos. Chem. Phys. 3, 509-520.

Kundu, S., Kawamura, K., Andreae, T.W., Hoffer, A., Andreae, M.O., 2010a. Diurnal variation in the water-soluble inorganic ions, organic carbon and isotopic compositions of total carbon and nitrogen 
in biomass burning aerosols from the LBA-SMOCC campaign in Rondonia, Brazil. J. Aerosol Sci. 41, 118-133.

Kundu, S., Kawamura, K., Andreae, T.W., Hoffer, A., Andreae, M.O., 2010b. Molecular distributions of dicarboxylic acids, ketocarboxylic acids and $\alpha$-dicarbonyls in biomass burning aerosols: implications for photochemical production and degradation in smoke layers. Atmos. Chem. Phys. 10, 2209-2225.

Leaitch, W.R., Li S.-M., Liu P.S.K., Banic C.M., Macdonald A.M., Isaac G.A., Couture M.D., J.W., S., 1996. Relationships among CCN, aerosol size distribution and ion chemistry from airborne measurements over the Bay of Fundy in August-September 1995, in: al., K.M.e. (Ed.), Nucleation and Atmospheric Aerosols. Elsevier, Amsterdam, pp. 840-843.

Legrand, M., Preunkert, S., Oliveira, T., Pio, C.A., Hammer, S., Gelencser, A., Kasper-Giebl, A., Laj, P., 2007. Origin of $\mathrm{C} 2-\mathrm{C} 5$ dicarboxylic acids in the European atmosphere inferred from year-round aerosol study conducted at a west-east transect. J. Geophys. Res.-Atmos. 112, D23s07, doi:10.1029/2006jd008019.

Liggio, J., Li, S.M., McLaren, R., 2005. Reactive uptake of glyoxal by particulate matter. J. Geophys. Res.-Atmos. 110.

Lim, H.J., Carlton, A.G., Turpin, B.J., 2005. Isoprene forms secondary organic aerosol through cloud processing: Model simulations. Environ. Sci. Technol. 39, 4441-4446.

Menon, S., Hansen, J., Nazarenko, L., Luo, Y., 2002. Climate effects of black carbon aerosols in China and India. Science 297, 2250-2253.

Miyazaki, Y., Aggarwal, S.G., Singh, K., Gupta, P.K., Kawamura, K., 2009. Dicarboxylic acids and water-soluble organic carbon in aerosols in New Delhi, India, in winter: Characteristics and formation processes. J. Geophys. Res.-Atmos 114, D19206.

Myriokefalitakis, S., Tsigaridis, K., Mihalopoulos, N., Sciare, J., Nenes, A., Kawamura, K., Segers, A., Kanakidou, M., 2011. In-cloud oxalate formation in the global troposphere: a 3-D modeling study. Atmos. Chem. Phys. 11, 5761-5782.

Narukawa, M., Kawamura, K., Takeuchi, N., Nakajima, T., 1999. Distribution of dicarboxylic acids and carbon isotopic compositions in aerosols from 1997 Indonesian forest fires. Geophys. Res. Lett. 26, 3101-3104.

Pavuluri, C.M., Kawamura, K., 2012. Evidence for 13-carbon enrichment in oxalic acid via iron catalyzed photolysis in aqueous phase. Geophys. Res. Lett. 39, doi: 10.1029/2011GL050398.

Richter, A., Burrows, J.P., Nuss, H., Granier, C., Niemeier, U., 2005. Increase in tropospheric nitrogen dioxide over China observed from space. Nature 437, 129-132.

Sorooshian, A., Ng, N.L., Chan, A.W.H., Feingold, G., Flagan, R.C., Seinfeld, J.H., 2007. Particulate organic acids and overall water-soluble aerosol composition measurements from the 2006 Gulf of Mexico Atmospheric Composition and Climate Study (GoMACCS). J. Geophys. Res.-Atmos. 112, doi: 10.1029/2007JD008537.

Stephanou, E.G., Stratigakis, N., 1993. Oxocarboxylic and Alpha,Omega-Dicarboxylic Acids Photooxidation Products of Biogenic Unsaturated Fatty-Acids Present in Urban Aerosols. Environ. Sci. Technol. 27, 1403-1407.

Streets, D.G., Bond, T.C., Lee, T., Jang, C., 2004. On the future of carbonaceous aerosol emissions. J. Geophys. Res.-Atmos. 109, D24212, doi:24210.21029/22004JD004902.

Volkamer, R., Platt, U., Wirtz, K., 2001. Primary and secondary glyoxal formation from aromatics: Experimental evidence for the bicycloalkyl-radical pathway from benzene, toluene, and p-xylene. J. Phys. Chem. A 105, 7865-7874.

Wang, G., Niu, S., Liu, C., Wang, L., 2002. Identification of dicarboxylic acids and aldehyde of $\mathrm{PM}_{10}$ and $\mathrm{PM}_{2.5}$ aerosols in Nanjing, China. Atmos. Environ. 36, 1941-1950.

Warneck, P., 2003. In-cloud chemistry opens pathway to the formation of oxalic acid in the marine atmosphere. Atmos. Environ. 37, 2423-2427.

Warneck, P., 2005. Multi-phase chemistry of C-2 and C-3 organic compounds in the marine atmosphere. J. Atmos. Chem. 51, 119-159.

Warneke, C., de Gouw, J.A., Goldan, P.D., Kuster, W.C., Williams, E.J., Lerner, B.M., Jakoubek, R., Brown, S.S., Stark, H., Aldener, M., Ravishankara, A.R., Roberts, J.M., Marchewka, M., Bertman, S., Sueper, D.T., McKeen, S.A., Meagher, J.F., Fehsenfeld, F.C., 2004. Comparison of daytime and nighttime oxidation of biogenic and anthropogenic VOCs along the New England coast in summer during New England Air Quality Study 2002. J. Geophys. Res.-Atmos. 109. 
Wolff, G.T., Korsog, P.E., 1985. Estimates of the contributions of sources to inhalable particulate concentrations in Detroit. Atmos. Environ. 19, 1399-1409.

Yokouchi, Y., Ambe, Y., 1986. Characterization of Polar Organics in Airborne Particulate Matter. Atmos. Environ. 20, 1727-1734.

Yu, S.C., 2000. Role of organic acids (formic, acetic, pyruvic and oxalic) in the formation of cloud condensation nuclei (CCN): a review. Atmos. Res. 53, 185-217.

Zhu, X., Prospero, J.M., Savoie, D.L., Millero, F.J., Zika, R.G., Saltzman, E.S., 1993. Photoreduction of Iron(III) in Marine Mineral Aerosol Solutions. J. Geophys. Res.-Atmos. 98, 9039-9046.

Zimmermann, J., Poppe, D., 1996. A supplement for the RADM2 chemical mechanism: The photooxidation of isoprene. Atmos. Environ. 30, 1255-1269.

Zuo, Y.G., Hoigne, J., 1992. Formation of Hydrogen-Peroxide and Depletion of Oxalic-Acid in Atmospheric Water by Photolysis of Iron (III) Oxalato Complexes. Environ. Sci. Technol. 26, 1014-1022.

Zuo, Y.G., Hoigne, J., 1994. Photochemical Decomposition of Oxalic, Glyoxalic and Pyruvic-Acid Catalyzed by Iron in Atmospheric Waters. Atmos. Environ. 28, 1231-1239.

Zuo, Y.G., Zhan, J., 2005. Effects of oxalate on Fe-catalyzed photoxidation of dissolved sulfur dioxide in atmospheric water. Atmos. Environ. 39, 27-37. 
Table 1. Fractions of local wind directions at Mangshan site, north of Beijing.

\begin{tabular}{ccc}
\hline Wind Directions & Daytime (\%) & Nighttime (\%) \\
\hline Northeast & 23.45 & 99.56 \\
Southeast & 6.21 & 0.44 \\
Southwest & 69.66 & 0 \\
Northwest & 0.69 & 0 \\
\hline
\end{tabular}


Table 2. Concentrations of dicarboxylic acids, oxocarboxylic acids, $\alpha$-dicarbonyls and bulk parameters in aerosol samples from Mangshan, China.

\begin{tabular}{|c|c|c|c|c|c|c|c|c|}
\hline \multirow[b]{2}{*}{ Component } & \multicolumn{4}{|c|}{ Daytime $(\mathrm{n}=38)$} & \multicolumn{4}{|c|}{ Nighttime $(\mathrm{n}=20)$} \\
\hline & Min. & Max. & Ave. & S.D. & Min. & Max. & Ave. & S.D. \\
\hline \multicolumn{9}{|l|}{ Dicarboxylic acids $\left(\mathrm{ng} \mathrm{m}^{-3}\right)$} \\
\hline Oxalic, $\mathrm{C}_{2}$ & 53.2 & 1300 & 607 & 398 & 57.6 & 1879 & 806 & 604 \\
\hline Malonic, $\mathrm{C}_{3}$ & 29.3 & 233 & 123 & 67.9 & 16.6 & 169 & 88.5 & 47.6 \\
\hline Succinic, $\mathrm{C}_{4}$ & 11.0 & 270 & 115 & 72.0 & 11.1 & 286 & 107 & 72 \\
\hline Glutaric, $\mathrm{C}_{5}$ & 2.9 & 72.4 & 34.2 & 21.7 & 3.5 & 78.3 & 27.8 & 19.9 \\
\hline Adipic, $\mathrm{C}_{6}$ & 1.4 & 44.1 & 19.7 & 13.2 & 1.2 & 45.7 & 15.2 & 11.6 \\
\hline Pimeric, $\mathrm{C}_{7}$ & N.D. & 21.1 & 6.2 & 4.8 & 0.3 & 15.9 & 6.2 & 4.2 \\
\hline Suberic, $\mathrm{C}_{8}$ & N.D. & 24.3 & 1.2 & 3.9 & N.D. & 2.2 & 0.5 & 0.5 \\
\hline Azelaic, $\mathrm{C}_{9}$ & 1.1 & 74.4 & 24.0 & 17.7 & 1.8 & 64.1 & 27.8 & 17.8 \\
\hline Sebaric, $\mathrm{C}_{10}$ & N.D. & 5.8 & 2.6 & 1.6 & 0.3 & 5.0 & 1.9 & 1.2 \\
\hline Undecanedioic, $\mathrm{C}_{11}$ & N.D. & 5.3 & 1.6 & 1.6 & 0.1 & 7.7 & 2.8 & 2.2 \\
\hline Dodecanedioic, $\mathrm{C}_{12}$ & N.D. & 1.6 & 0.6 & 0.6 & 0.1 & 5.6 & 1.3 & 1.6 \\
\hline Methylmalonic, $\mathrm{iC}_{4}$ & 0.2 & 11.5 & 6.2 & 2.9 & 1.3 & 6.8 & 3.9 & 2.0 \\
\hline Methylsuccinic, $\mathrm{iC}_{5}$ & 1.4 & 37.8 & 14.2 & 8.7 & 1.2 & 26.7 & 12.8 & 8.2 \\
\hline 2-Methylglutaric, $\mathrm{iC}_{6}$ & 0.3 & 8.6 & 2.4 & 2.0 & 0.2 & 19.5 & 3.0 & 4.1 \\
\hline Maleic, M & 0.4 & 84.3 & 15.3 & 24.1 & 0.1 & 135 & 18.7 & 29.4 \\
\hline Fumaric, F & 1.3 & 16.4 & 7.2 & 4.1 & 1.4 & 19.0 & 8.6 & 5.3 \\
\hline Methylmaleic, mM & 1.3 & 26.0 & 9.1 & 6.1 & 0.8 & 25.7 & 9.3 & 7.3 \\
\hline Malic, hC4 & N.D. & 11.9 & 3.3 & 3.0 & 0.1 & 9.3 & 1.3 & 1.9 \\
\hline Phthalic, $\mathrm{Ph}$ & 7.0 & 218 & 66.7 & 5.6 & 5.0 & 203 & 42.4 & 4.4 \\
\hline Isophthalic, $\mathrm{iPh}$ & 0.4 & 18.0 & 8.1 & 7.6 & 0.8 & 15.3 & 6.9 & 6.5 \\
\hline Terephthalic, tPh & 0.6 & 29.8 & 9.9 & 44.2 & 0.3 & 21.5 & 10.3 & 43.0 \\
\hline Ketomalonic, $\mathrm{kC}_{3}$ & 0.4 & 6.5 & 2.6 & 1.6 & 0.4 & 5.3 & 1.7 & 1.2 \\
\hline 4-Ketopimelic, $\mathrm{kC}_{7}$ & N.D. & 16.2 & 6.1 & 4.6 & 0.5 & 10.3 & 4.1 & 3.0 \\
\hline Total diacids & 122 & 2384 & 1088 & 671 & 105 & 3056 & 1208 & 829 \\
\hline \multicolumn{9}{|l|}{ Oxocarboxylic acids $\left(\mathrm{ng} \mathrm{m}^{-3}\right)$} \\
\hline Pyruvic & 2.0 & 73.8 & 24.7 & 18.1 & 1.5 & 67.0 & 21.0 & 18.8 \\
\hline Glyoxylic, $\omega \mathrm{C}_{2}$ & 11.8 & 195 & 82.1 & 54.0 & 10.1 & 121 & 58.6 & 32.4 \\
\hline 3-Oxopropanoic, $\omega_{3}$ & 2.6 & 47.0 & 19.1 & 13.8 & 1.8 & 17.6 & 7.8 & 4.1 \\
\hline 4-Oxobutanoic, $\omega \mathrm{C}_{4}$ & 2.4 & 35.0 & 17.3 & 9.8 & 0.9 & 23.2 & 10.5 & 6.5 \\
\hline 7-Oxoheptanoic, $\omega \mathrm{C}_{7}$ & 0.5 & 14.0 & 5.8 & 3.3 & 1.0 & 13.2 & 5.5 & 3.4 \\
\hline 8-Oxooctanoic, $\omega \mathrm{C}_{8}$ & 0.4 & 14.1 & 5.9 & 3.8 & 0.7 & 18.1 & 7.5 & 4.7 \\
\hline 9-Oxononanoic, $\omega \mathrm{C}_{9}$ & N.D. & 11.6 & 3.9 & 3.2 & 0.1 & 15.4 & 5.5 & 4.4 \\
\hline Total oxoacids & 23.0 & 340 & 159 & 95 & 12.7 & 232 & 97.9 & 64.8 \\
\hline \multicolumn{9}{|l|}{$\alpha$-Dicarbonyls $\left(\mathrm{ng} \mathrm{m}^{-3}\right.$ ) } \\
\hline Glyoxal, Gly & 3.1 & 35.3 & 14.9 & 8.8 & 2.6 & 33.8 & 12.6 & 7.9 \\
\hline Methylglyoxal, MeGly & 1.0 & 242 & 36.6 & 50.7 & 1.0 & 255 & 47.2 & 66.3 \\
\hline Total dicarbonyls & 5.3 & 271 & 51.5 & 56.9 & 3.6 & 289 & 59.8 & 70.1 \\
\hline \multicolumn{9}{|l|}{ Bulk analyses } \\
\hline Aerosol mass $\left(\mu \mathrm{g} \mathrm{m}^{-3}\right)$ & 47.8 & 603 & 267 & 129 & 29.4 & 270 & 146 & 78.6 \\
\hline Total carbon (TC) $\left(\mu \mathrm{g} \mathrm{m}^{-3}\right)$ & 5.8 & 51.3 & 24.9 & 13.4 & 3.5 & 34.5 & 16.9 & 9.5 \\
\hline
\end{tabular}

N.D. = Not Detected; Detection limit is ca. $0.1 \mathrm{ng} \mathrm{m}^{-3}$.

Note: All the numerical data in this table, except integers, show one decimal place. 
Table 3. Results of principal component analysis of organic compounds in daytime/nighttime Mangshan aerosols.

\begin{tabular}{|c|c|c|c|c|c|c|c|}
\hline \multirow[b]{2}{*}{ Compounds } & \multicolumn{3}{|c|}{ Daytime $(\mathrm{n}=38)$} & \multicolumn{4}{|c|}{ Nighttime $(n=20)$} \\
\hline & $\begin{array}{c}\text { Component } \\
1\end{array}$ & $\begin{array}{c}\text { Component } \\
2 \\
\end{array}$ & $\begin{array}{c}\text { Component } \\
3 \\
\end{array}$ & $\begin{array}{c}\text { Component } \\
1 \\
\end{array}$ & $\begin{array}{c}\text { Component } \\
2 \\
\end{array}$ & $\begin{array}{c}\text { Component } \\
3 \\
\end{array}$ & $\begin{array}{c}\text { Component } \\
4\end{array}$ \\
\hline \multicolumn{8}{|l|}{ Dicarboxylic acids } \\
\hline Oxalic, $\mathrm{C}_{2}$ & 0.68 & 0.59 & 0.36 & 0.42 & 0.49 & 0.30 & 0.60 \\
\hline Malonic, $\mathrm{C}_{3}$ & 0.74 & 0.35 & 0.48 & 0.63 & 0.60 & 0.30 & 0.33 \\
\hline Succinic, $\mathrm{C}_{4}$ & 0.55 & 0.64 & 0.45 & 0.79 & 0.46 & 0.28 & 0.10 \\
\hline Glutaric, $\mathrm{C}_{5}$ & 0.70 & 0.56 & 0.36 & 0.83 & 0.47 & 0.21 & 0.11 \\
\hline Adipic, $\mathrm{C}_{6}$ & 0.75 & 0.53 & 0.22 & 0.60 & 0.75 & 0.18 & 0.11 \\
\hline Pimeric, $\mathrm{C}_{7}$ & 0.58 & 0.75 & -0.02 & 0.33 & 0.88 & 0.22 & 0.11 \\
\hline Suberic, $\mathrm{C}_{8}$ & -0.01 & 0.02 & 0.03 & 0.26 & 0.13 & 0.82 & 0.30 \\
\hline Azelaic, $\mathrm{C}_{9}$ & 0.52 & 0.69 & 0.14 & 0.39 & 0.81 & 0.17 & 0.18 \\
\hline Sebaric, $\mathrm{C}_{10}$ & 0.27 & 0.27 & 0.69 & 0.30 & 0.19 & 0.29 & 0.80 \\
\hline Undecanedioic, $\mathrm{C}_{11}$ & 0.40 & 0.64 & 0.35 & -0.03 & 0.91 & 0.22 & 0.08 \\
\hline Dodecanedioic, $\mathrm{C}_{12}$ & 0.64 & 0.41 & 0.34 & 0.86 & 0.25 & -0.05 & 0.07 \\
\hline Methylmalonic, $\mathrm{iC}_{4}$ & 0.83 & 0.16 & 0.26 & 0.64 & 0.53 & 0.16 & 0.35 \\
\hline Methylsuccinic, $\mathrm{iC}_{5}$ & 0.44 & 0.64 & 0.59 & 0.62 & 0.58 & 0.20 & 0.21 \\
\hline 2-Methylglutaric, $\mathrm{iC}_{6}$ & 0.13 & 0.87 & 0.16 & 0.18 & 0.17 & 0.93 & 0.09 \\
\hline Maleic, M & 0.17 & 0.23 & 0.80 & 0.09 & 0.11 & 0.04 & 0.90 \\
\hline Fumaric, F & 0.55 & 0.43 & 0.60 & 0.57 & 0.62 & 0.27 & 0.24 \\
\hline Methylmaleic, mM & 0.36 & 0.78 & 0.41 & 0.68 & 0.45 & 0.42 & 0.06 \\
\hline Malic, hC4 & 0.40 & 0.11 & 0.57 & 0.03 & 0.13 & 0.96 & 0.06 \\
\hline Phthalic, $\mathrm{Ph}$ & 0.64 & 0.39 & 0.60 & 0.67 & 0.43 & 0.46 & 0.27 \\
\hline Isophthalic, $\mathrm{iPh}$ & 0.40 & 0.72 & 0.44 & 0.40 & 0.71 & 0.16 & 0.48 \\
\hline Terephthalic, $\mathrm{tPh}$ & 0.44 & 0.49 & 0.59 & 0.92 & -0.03 & 0.15 & 0.13 \\
\hline Ketomalonic, $\mathrm{kC}_{3}$ & 0.80 & 0.34 & 0.17 & 0.48 & 0.43 & 0.73 & 0.05 \\
\hline 4-Ketopimelic, $\mathrm{kC}_{7}$ & 0.86 & 0.11 & 0.38 & 0.72 & 0.42 & 0.28 & 0.39 \\
\hline \multicolumn{8}{|l|}{ Oxocarboxylic acids } \\
\hline Pyruvic, Pyr & 0.52 & 0.32 & 0.21 & 0.83 & 0.13 & 0.25 & 0.20 \\
\hline Glyoxylic, $\omega \mathrm{C}_{2}$ & 0.53 & 0.39 & 0.68 & 0.40 & 0.38 & 0.31 & 0.33 \\
\hline 3-Oxopropanoic, $\omega \mathrm{C}_{3}$ & 0.58 & 0.11 & 0.71 & 0.55 & 0.36 & 0.61 & 0.26 \\
\hline 4-Oxobutanoic, $\omega \mathrm{C}_{4}$ & 0.72 & 0.33 & 0.55 & 0.71 & 0.49 & 0.33 & 0.05 \\
\hline 7-Oxoheptanoic, $\omega \mathrm{C}_{7}$ & 0.63 & 0.33 & 0.39 & 0.77 & 0.28 & 0.35 & 0.35 \\
\hline 8-Oxooctanoic, $\omega \mathrm{C}_{8}$ & 0.73 & 0.26 & 0.50 & 0.43 & 0.79 & 0.25 & 0.13 \\
\hline 9-Oxononanoic, $\omega \mathrm{C}_{9}$ & 0.55 & 0.76 & 0.08 & 0.74 & 0.48 & 0.28 & 0.15 \\
\hline \multicolumn{8}{|l|}{$\alpha$-Dicarbonyls } \\
\hline Glyoxal, Gly & 0.43 & 0.58 & 0.58 & 0.47 & 0.34 & 0.67 & 0.08 \\
\hline Methylglyoxal, MeGly & -0.04 & 0.79 & 0.28 & 0.03 & 0.23 & 0.00 & -0.02 \\
\hline Variance $(\%)$ & 31.4 & 26.0 & 20.7 & 32.5 & 24.6 & 17.3 & 10.0 \\
\hline
\end{tabular}

Data sets of the 16 samples were subjected to PCA analysis with SPSS software (version 16.0).

Because of sharp drops in eigenvalue for factor 4 in daytime samples and factor 5 in nighttime samples, those results are not given here. 


\section{Figure captions}

Figure 1. A map of Beijing and its vicinity with the sampling site at Mangshan (white star).

Figure 2. Temporal variations of (a) total aerosol masses $\left(\mu \mathrm{g} \mathrm{m}^{-3}\right)$, (b) total carbon concentrations $\left(\mu \mathrm{g} \mathrm{m}^{-3}\right)$ and (c) proportion of TC in bulk aerosols in Mangshan TSP samples. The hollow circle represents daytime sample and the solid circle represents nighttime sample.

Figure 3. (a) Averaged molecular distributions of dicarboxylic acids, oxocarboxylic acids and $\alpha$-dicarbonyls in the day and nighttime aerosols from Mangshan. (b)Temporal variationsin the concentrations $\left(\mathrm{ng} \mathrm{m}^{-3}\right.$ ) of water-soluble dicarboxylic acids, oxocarboxylic acids and $\alpha$-dicarbonyls in the ambient aerosols from Mangshan.

Figure 4. Temporal variations in the contributions of total dicarboxylic acids and oxalic acid to aerosol total carbon (TC) in the ambient aerosols from Mangshan.

Figure 5. Correlation plots for the concentrations of (a) oxalic acid $\left(\mathrm{C}_{2}\right)$ and glyoxylic acid $\left(\omega \mathrm{C}_{2}\right)$, (b) oxalic acid $\left(\mathrm{C}_{2}\right)$ and malonic acid $\left(\mathrm{C}_{3}\right)$, and (c) oxalic acid $\left(\mathrm{C}_{2}\right)$ and succinic acid $\left(\mathrm{C}_{4}\right)$ in Mangshan aerosols for daytime and nighttime.

Figure 6. Photochemical formation mechanisms of $\omega \mathrm{C}_{8}, \omega \mathrm{C}_{9}$ and $\mathrm{C}_{9}$, as well as $\mathrm{C}_{4}, \mathrm{C}_{3}$ and $\mathrm{C}_{2}$ from biogenic unsaturated fatty acids emitted from higher plants, marine phytoplankton and domestic cooking. Modified from Kawamura et al. (1996a, 1996b) and Kawamura and Sakaguchi (1999).

Figure 7. Comparisons of the Manshan data with the results from previous studies in East Asia (1: Kawamura et al., 1996b; 2: Kawamura et al., 2010; 3: Kawamura et al., 2012; 4: Kawamura and Sakaguchi, 1999; 5: Kawamura and Ikushima, 1993; 6: Kundu et al., 2010a; 7: Ho et al., 2007; 8: Ho et al., 2010; 9: Kawamura et al., 2013). 


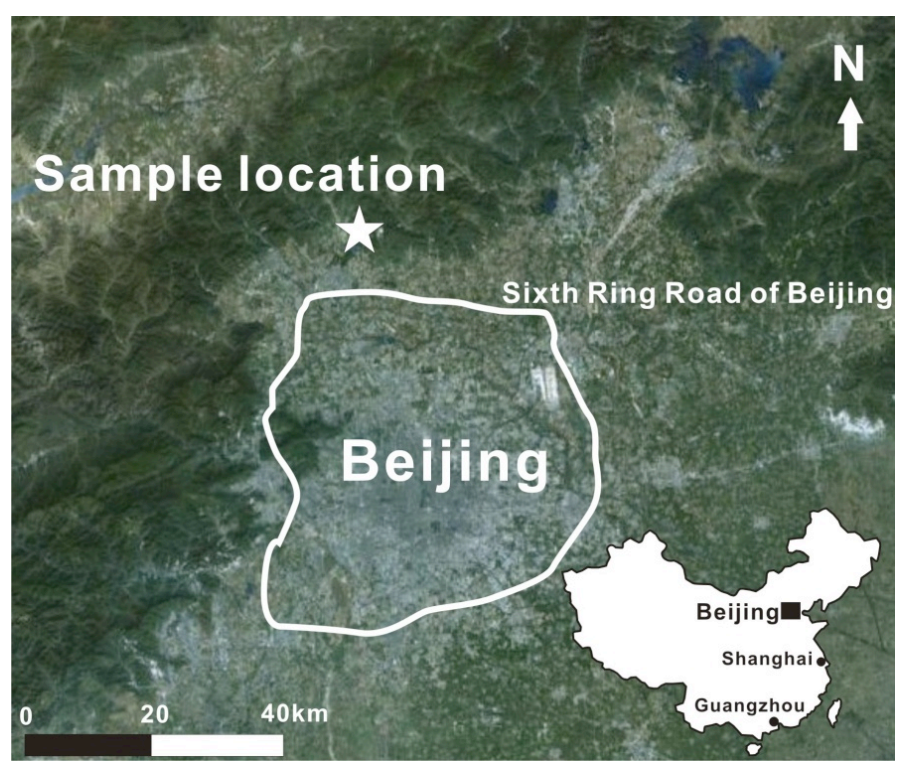

Figure 1. A map of Beijing and its vicinity with the sampling site at Mangshan (white star).

(a) Total aerosol mass

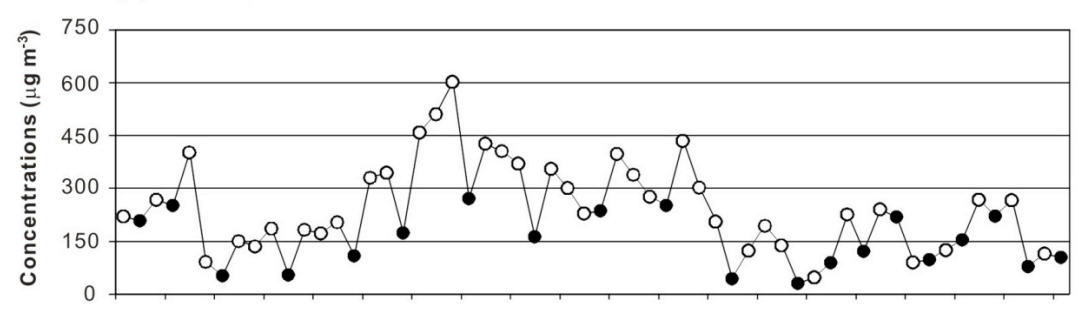

(b) Total carbon

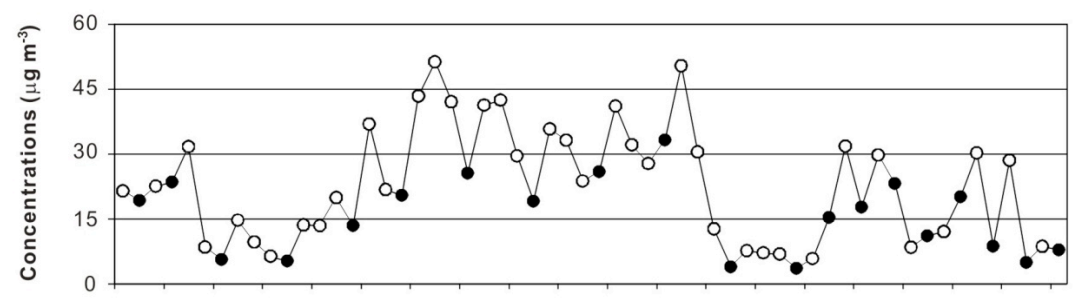

(c) TC/Aerosol mass

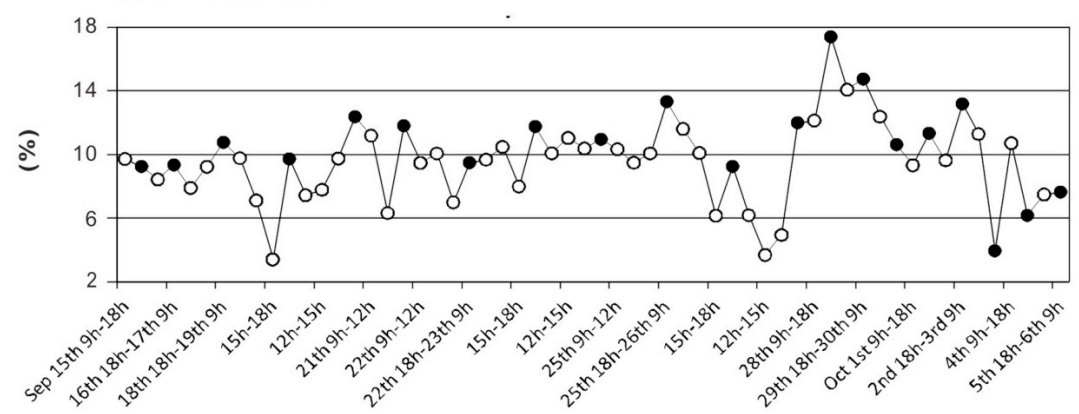

Figure 2. Temporal variations of (a) total aerosol masses $\left(\mu \mathrm{g} \mathrm{m}^{-3}\right)$, (b) total carbon concentrations ( $\mu \mathrm{g}$ $\mathrm{m}^{-3}$ ) and (c) proportion of TC in bulk aerosols in Mangshan TSP samples. The hollow circle represents daytime sample and the solid circle represents nighttime sample. 
(a)

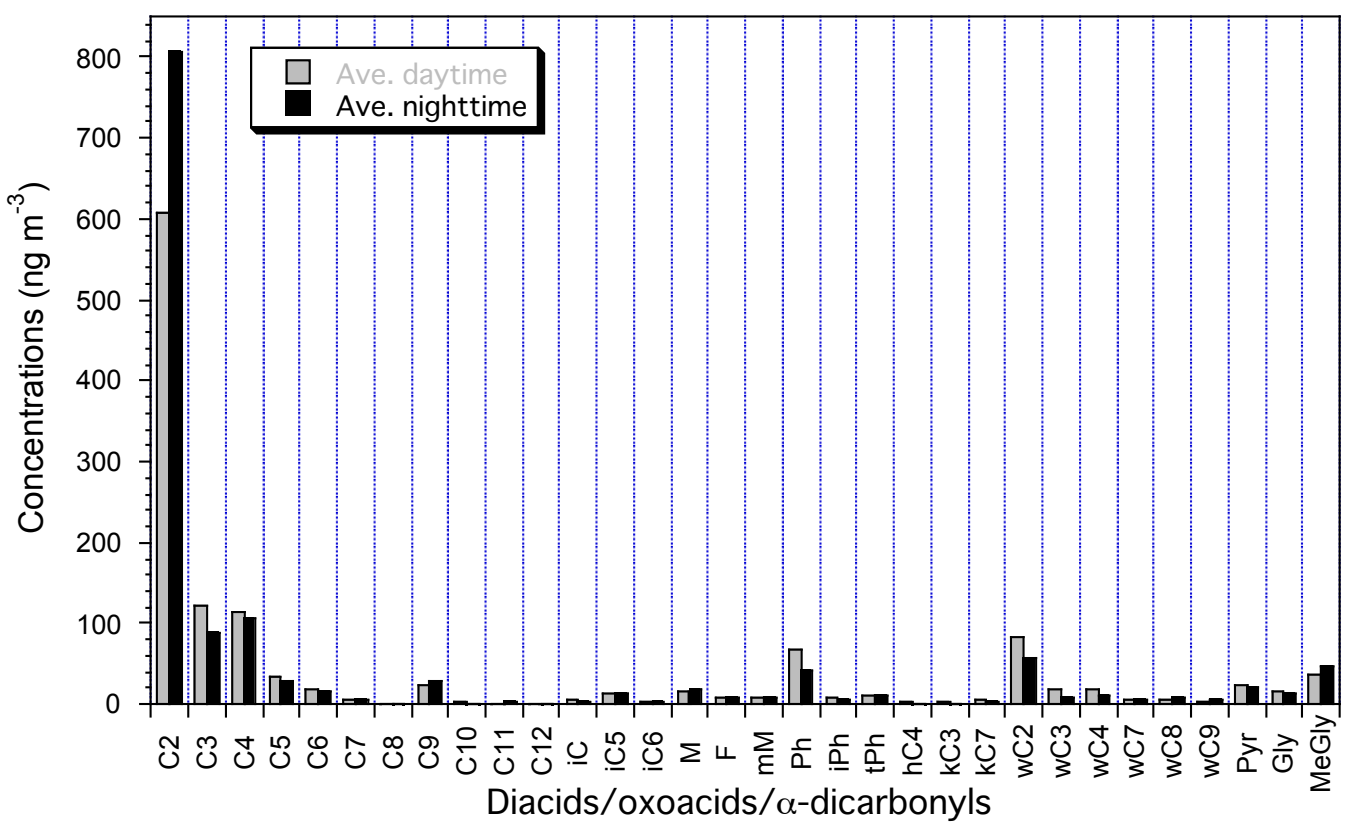

(b)

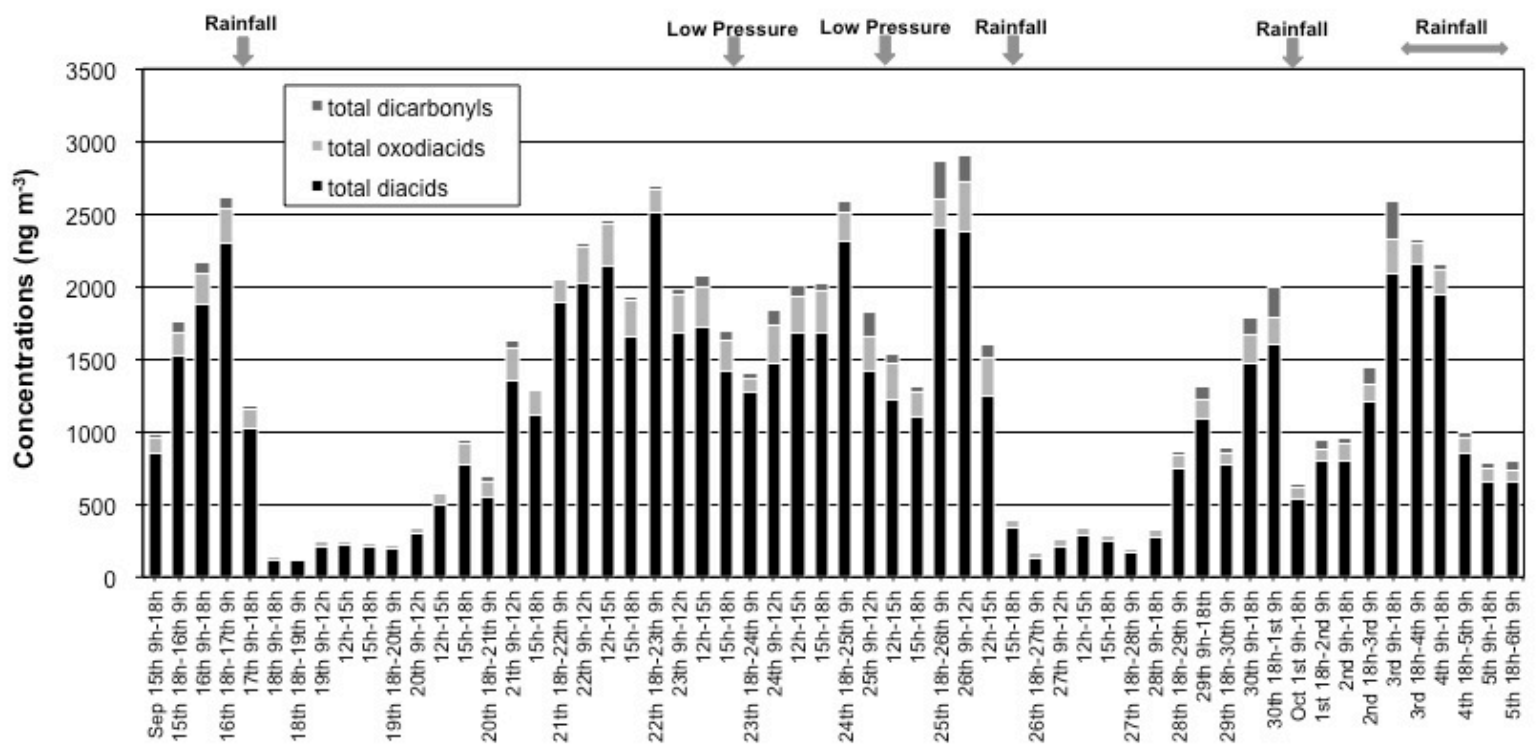

Sampling time (September and October, 2007)

Figure 3. (a) Averaged molecular distributions of dicarboxylic acids, oxocarboxylic acids and $\alpha$-dicarbonyls in the day and nighttime aerosols from Mangshan. (b) Temporal variations in the concentrations $\left(\mathrm{ng} \mathrm{m}^{-3}\right.$ ) of water-soluble dicarboxylic acids, oxocarboxylic acids and $\alpha$-dicarbonyls in the ambient aerosols from Mangshan. 


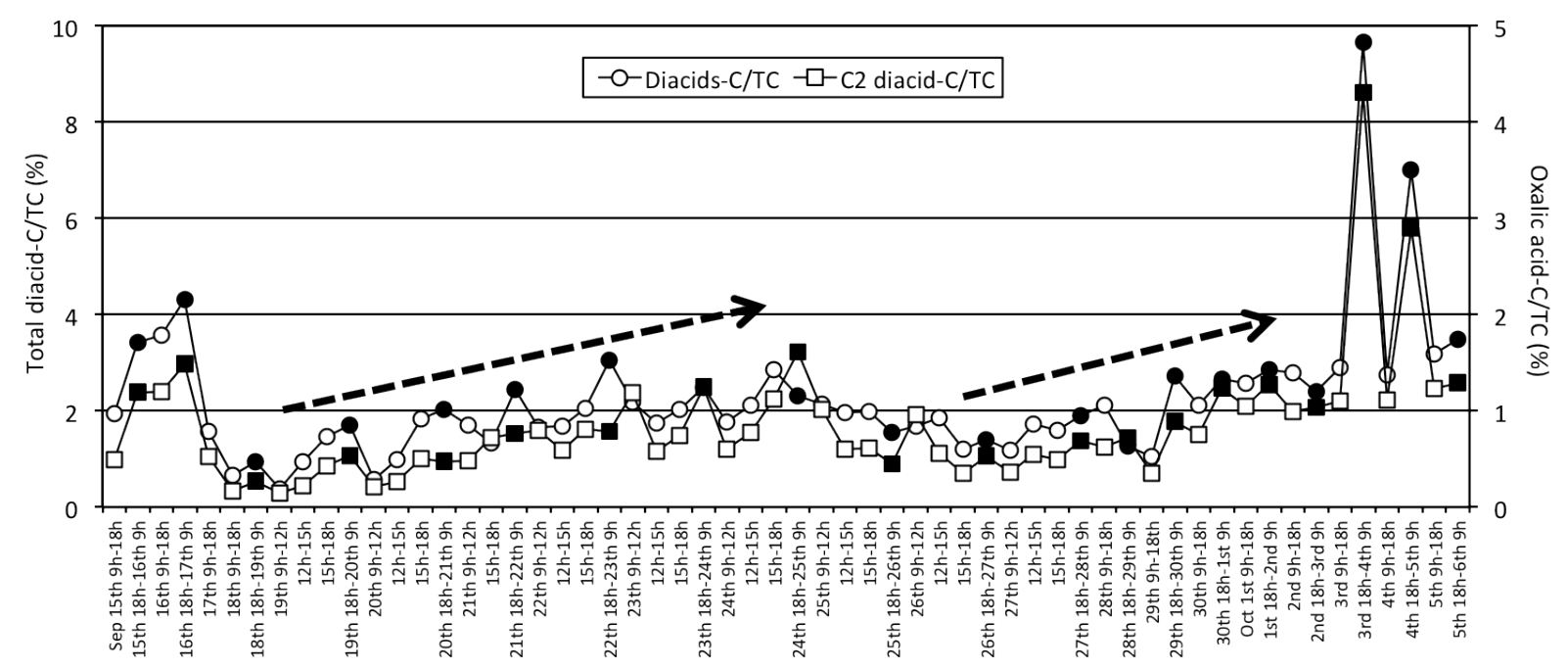

Figure 4. Temporal variations in the contributions of total dicarboxylic acids and oxalic acid to aerosol total carbon (TC) in the ambient aerosols from Mangshan. 

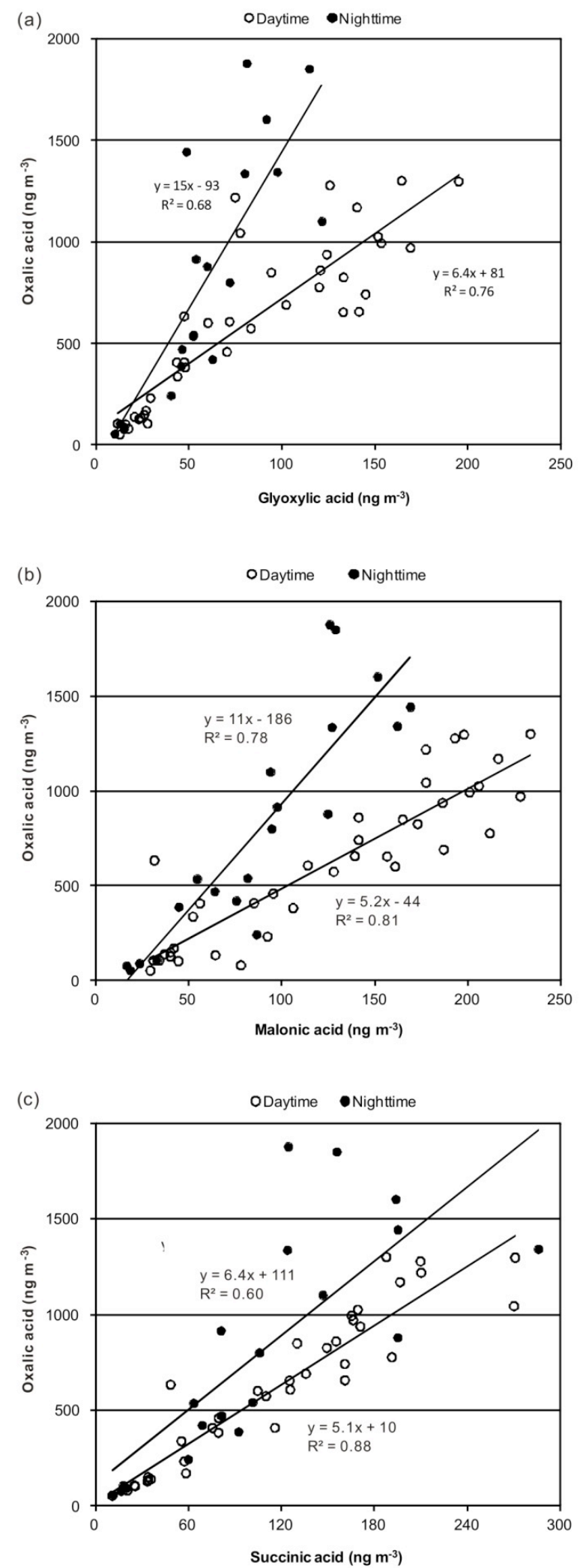

Figure 5. Correlation plots for the concentrations of (a) oxalic acid $\left(\mathrm{C}_{2}\right)$ and glyoxylic acid $\left(\omega \mathrm{C}_{2}\right)$, (b) oxalic acid $\left(\mathrm{C}_{2}\right)$ and malonic acid $\left(\mathrm{C}_{3}\right)$, and (c) oxalic acid $\left(\mathrm{C}_{2}\right)$ and succinic acid $\left(\mathrm{C}_{4}\right)$ in Mangshan aerosols for daytime and nighttime. 


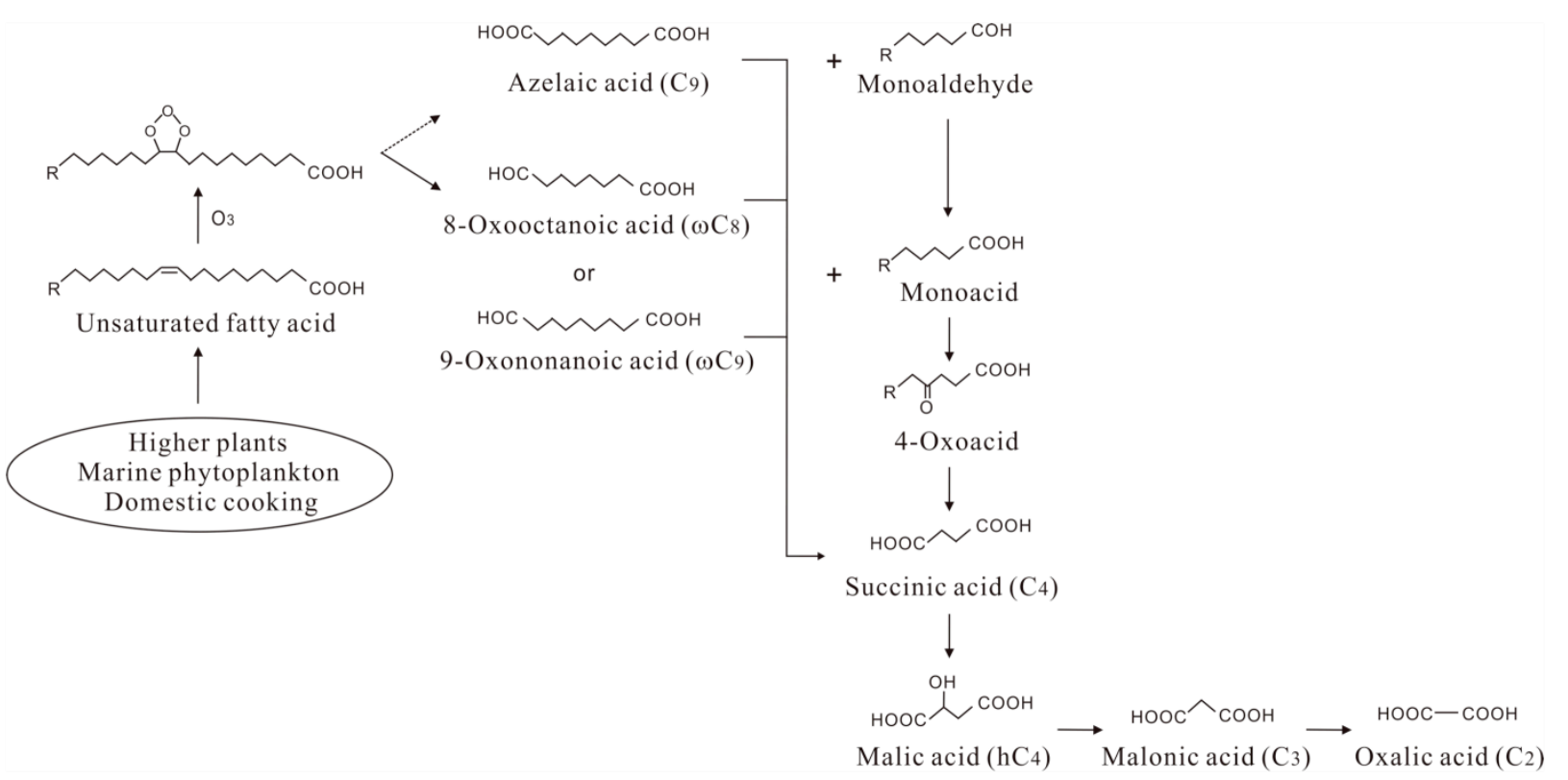

Figure 6. Photochemical formation mechanisms of $\omega C_{8}, \omega C_{9}$ and $C_{9}$, as well as $C_{4}, C_{3}$ and $C_{2}$ from biogenic unsaturated fatty acids emitted from higher plants, marine phytoplankton and domestic cooking. Modified from Kawamura et al. (1996a, 1996b) and Kawamura and Sakaguchi (1999).

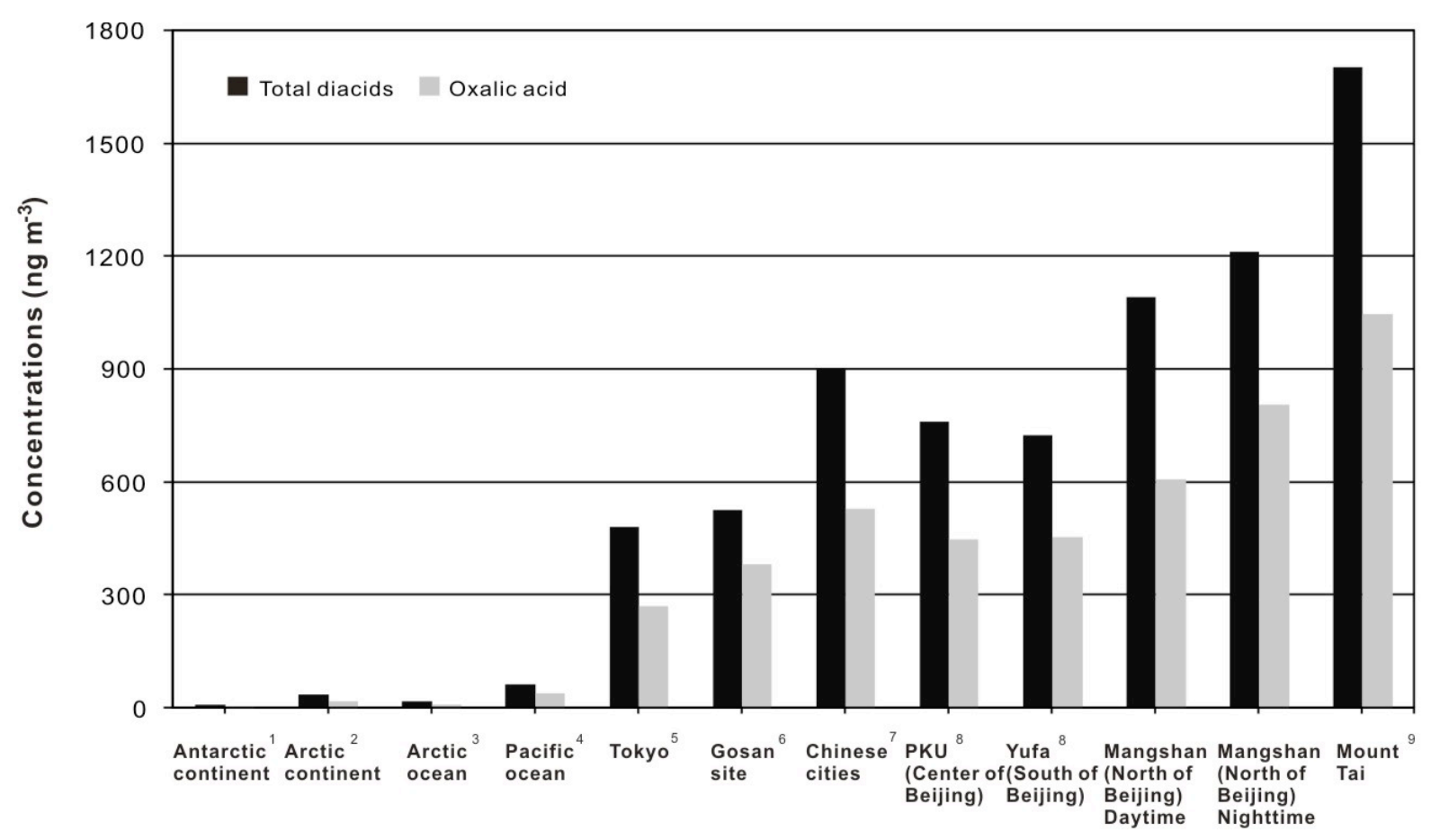

Figure 7. Comparisons of the Manshan data with the results from previous studies in East Asia (1:

Kawamura et al., 1996b; 2: Kawamura et al., 2010; 3: Kawamura et al., 2012; 4: Kawamura and Sakaguchi, 1999; 5: Kawamura and Ikushima, 1993; 6: Kundu et al., 2010a; 7: Ho et al., 2007; 8: Ho et al., 2010; 9: Kawamura et al., 2013). 


\section{Supporting Information}

(a)

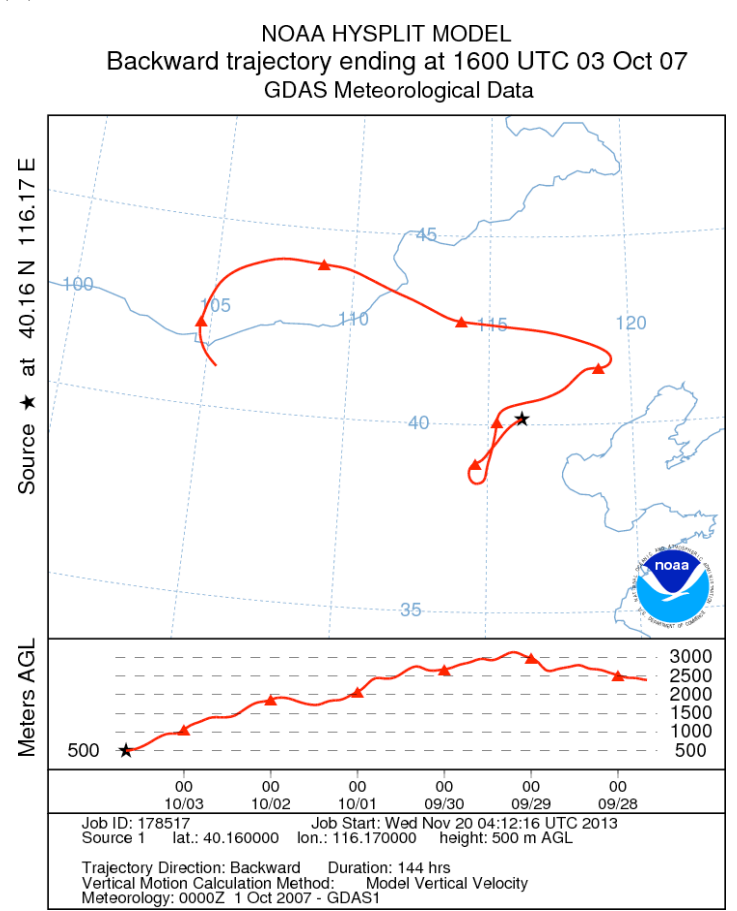

(b)

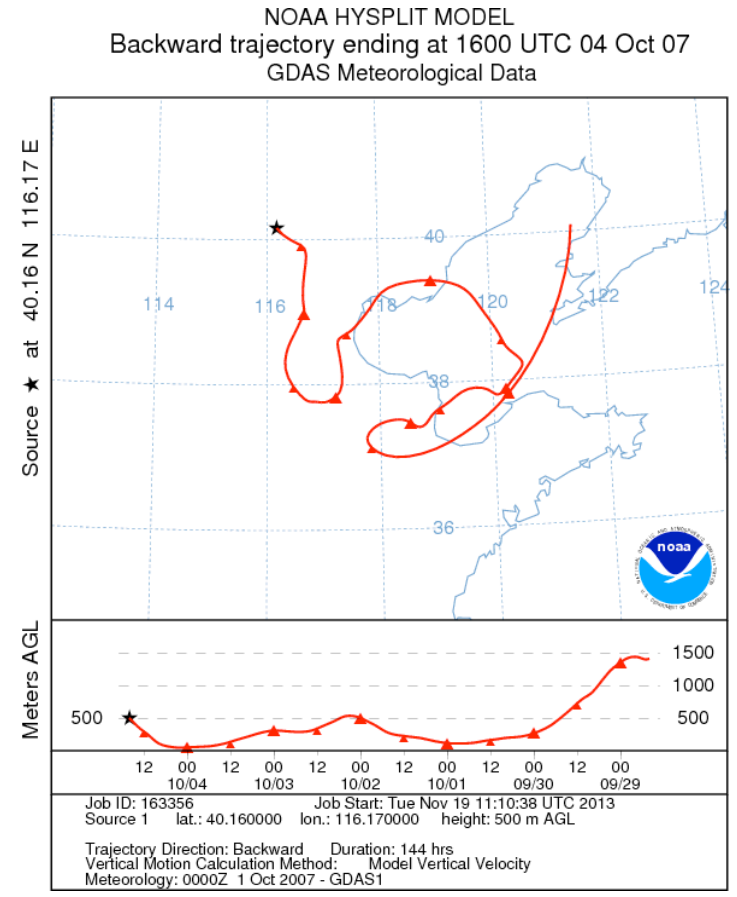

Figure S1. Backward air mass trajectories for the aerosol sample collected during (a) October 3-4 and (b) October 4-5, 2007 (local time is $00 \mathrm{~h}$ ) when higher peaks of diacid-C/TC were obtained (Figure 4). The trajectories were calculated for 6 days using the NOAA Hybrid Single-Particle Lagrangian Integrated Trajectory (Draxler and Ralph, 2013; Rolph 2013). 
(a) Phthalic acid/Total diacids ratios

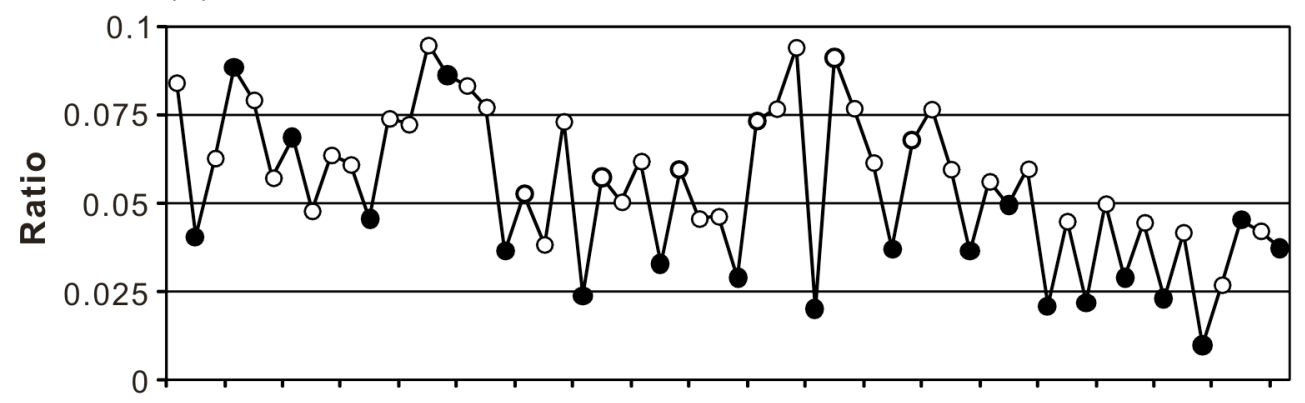

(b) $\mathrm{C}_{3} / \mathrm{C}_{4}$ diacid ratios

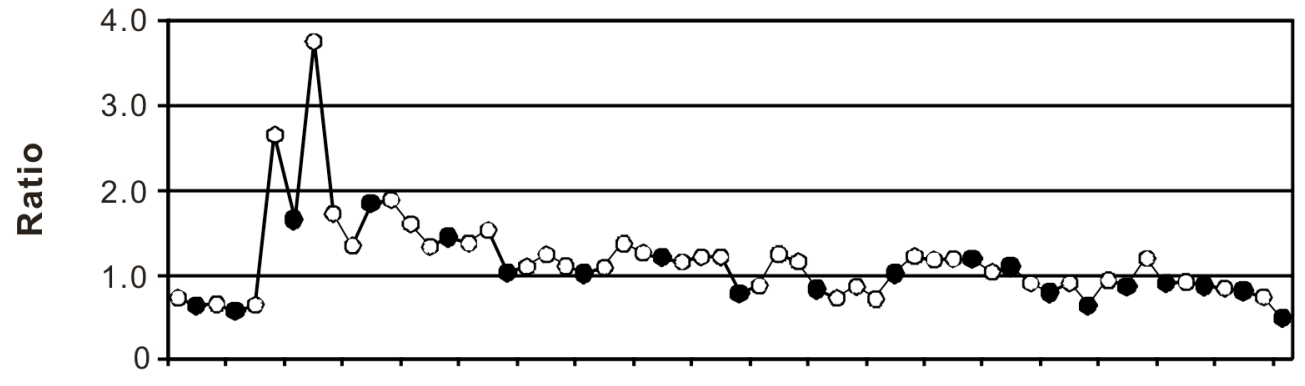

(c) $\mathrm{C}_{6} / \mathrm{C}_{9}$ diacid ratios

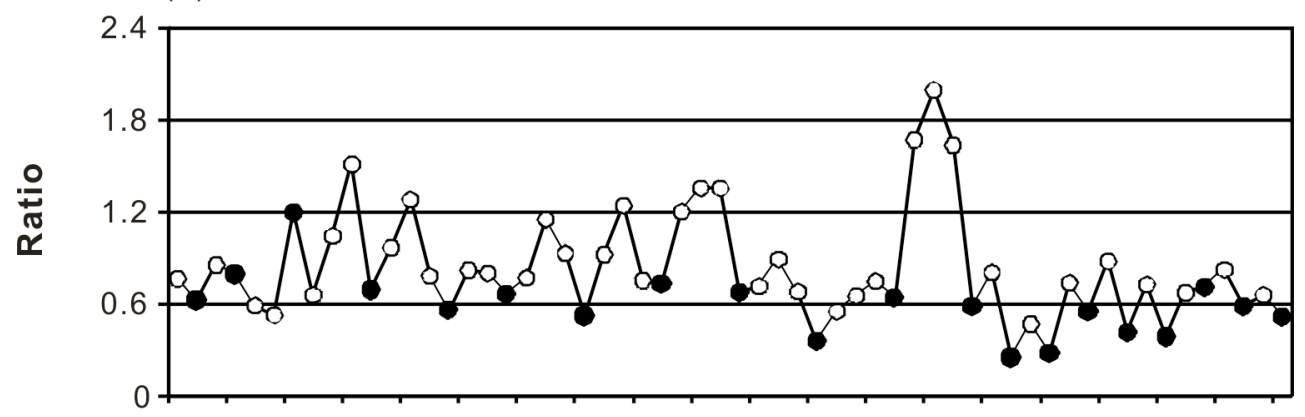

(d) $\mathrm{C}_{2} /$ Total diacids ratios

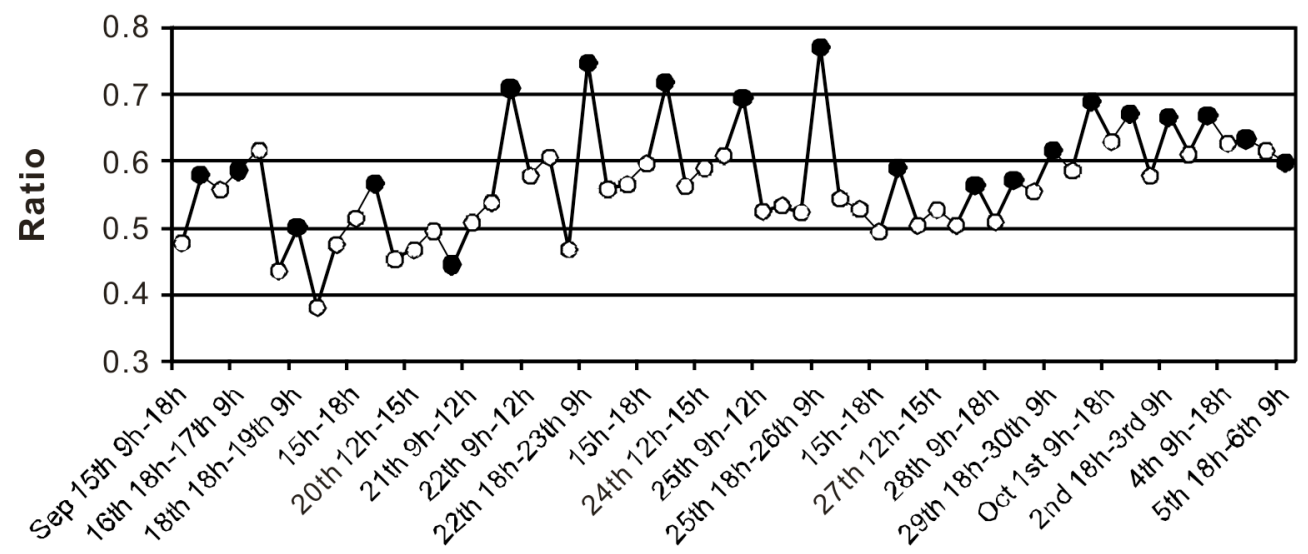

Figure S2. Temporal variations of (a) $\mathrm{Ph} /$ total diacid ratios, (b) $\mathrm{C}_{3} / \mathrm{C}_{4}$ diacid ratios, (c) $\mathrm{C}_{6} / \mathrm{C}_{9}$ diacid ratios and (d) $\mathrm{C}_{2}$ /total diacid ratios in Mangshan aerosols. The hollow circle represents daytime sample and the solid circle represents nighttime sample. 
(a) Daytime

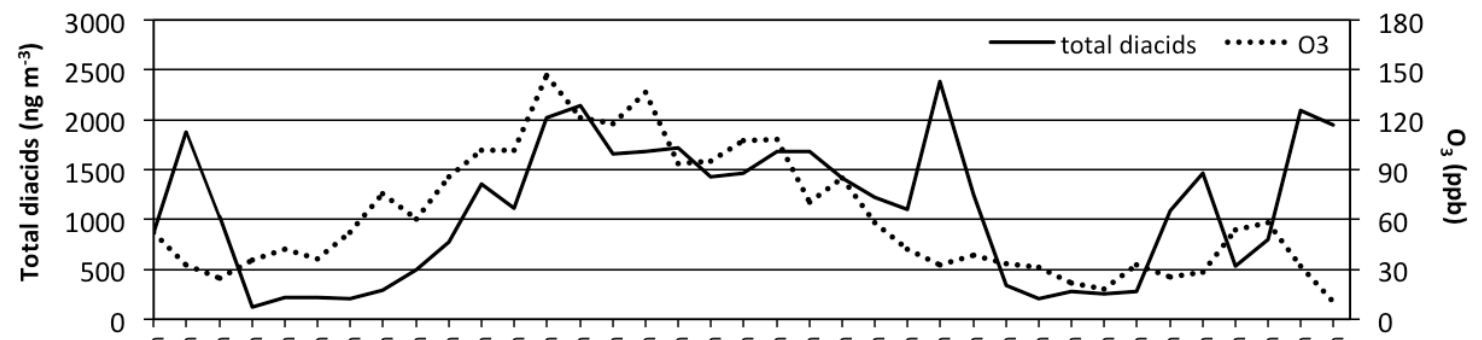

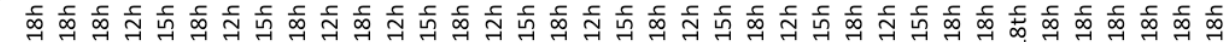

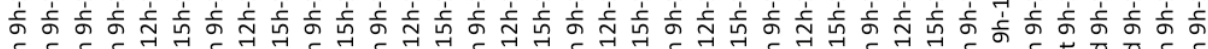

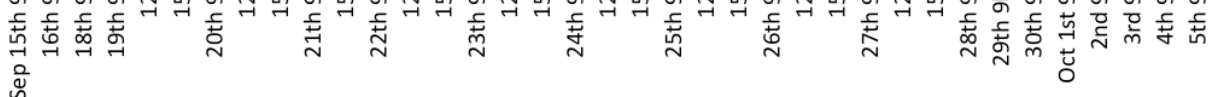

(b) Nighttime

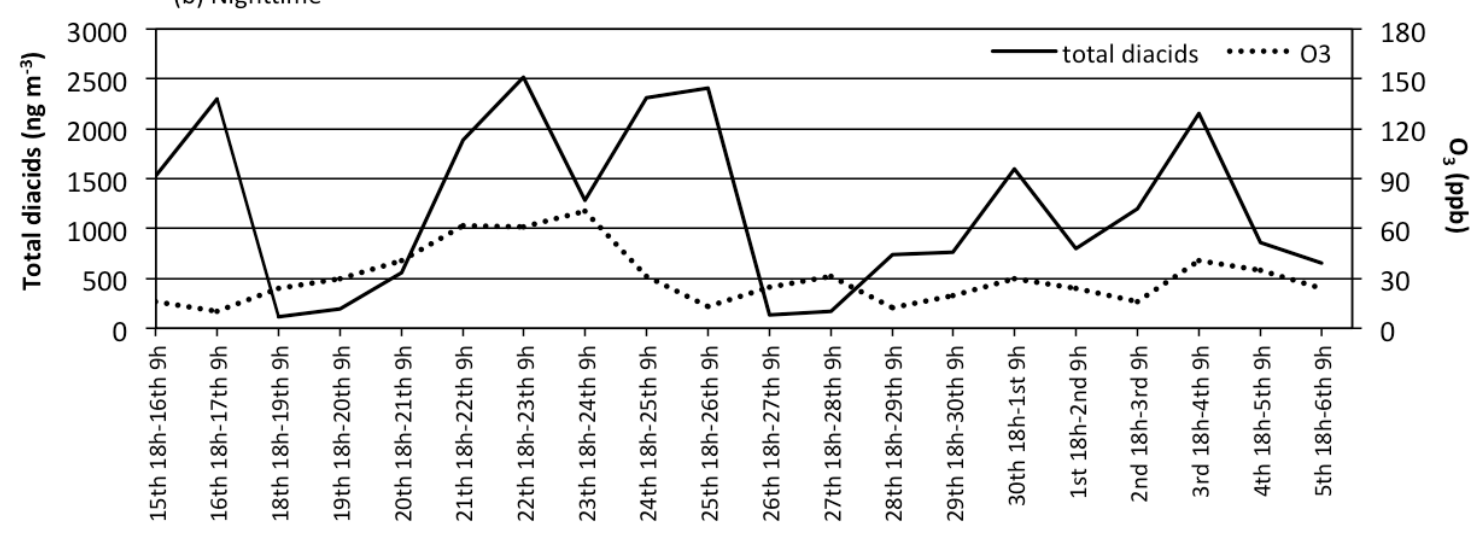

Figure S3. Temporal variations in the concentrations of total dicarboxylic acids and ozone in the atmosphere of Mangshan for (a) daytime and (b) nighttime. 